\title{
STUDI KELAYAKAN PADA USAHA PENERBIT IDE KREATIF
}

\author{
Mohamad Trio Febriyantoro \\ Universitas Universal \\ mtriofeb@gmail.com
}

\section{Profil Perusahaan}

Ide kreatif merupakan sebuah usaha bisnis yang bergerak dalam penerbitan buku independen yang didirikan oleh Mohamad Trio Febriyantoro dan Victor Yuwono pada tanggal 7 Januari 2012. Pelayanan dari usaha bisnis ini ditujukan untuk semua penulis yang ingin menerbitkan bukunya secara mandiri. Hal ini dikarenakan banyaknya penulis yang ingin menerbitkan bukunya, tetapi ditolak oleh beberapa penerbit dengan berbagai alasan. Adapun alasan tersebut misalnya kualitas tulisan belum sesuai standar penerbitan, tema tulisan tidak sesuai, dan masih banyak lagi. Alasan inilah yang kemudian menjadikan munculnya ide usaha bisnis Ide Kreatif yang berlokasi di Rungkut Kidul I nomor 11 Surabaya ini. Sampai saat ini, usaha bisnis ini dijalankan oleh kedua pendiri usaha dibantu dengan 2 pegawai yang bertugas sebagai editor dan pembuat desain

Salah satu buku yang telah diterbitkan oleh Ide Kreatif adalah sebuah buku motivasi yang berjudul "Awas Janda (Awas Jangan Abaikan Mimpi Anda)" yang ditulis oleh Trio Febryan. Buku tersebut telah tersebar di seluruh toko buku yang ada di Indonesia. Hal inilah yang menunjukkan perbedaan antara Ide Kreatif dengan penerbitan independen lainnya. Jika ada beberapa penerbit independen yang hanya bisa menerbitkan tanpa menyebarkan buku tersebut di toko-toko buku di seluruh Indonesia. Ide Kreatif memiliki ide bisnis tersendiri yang belum dilakukan beberapa penerbit independen. Hal ini juga digunakan untuk menarik 
perhatian penulis lain agar menerbitkan bukunya di Ide Kreatif. Selain Trio Febryan, ada beberapa penulis yang dibantu penerbitannya oleh Ide Kreatif, misalnya Laila dengan bukunya yang berjudul “Ada Kisah di Setiap Jejak dan Diaspora".

Akan tetapi semua usaha bisnis yang dilakukan, selalu ada kelemahan yang akan dialami, begitu pula dengan menjalankan usaha bisnis Ide Kreatif ini. Adapun permasalahan yang dialami oleh Ide Kreatif adalah arus kas yang tidak stabil. Hal ini dapat dimungkinkan karena berbagai hal, salah satunya karena Ide Kreatif merupakan penerbit independen. Oleh karenanya, manajemen Ide Kreatif akan melakukan pengembangan usaha bisnisnya dari penerbit independen menjadi penerbit konvensional. Dengan beralih menjadi penerbit konvensional, maka Ide Kreatif akan menangani proses produksi sampai pada percetakan saja. Sementara untuk saluran distribusi akan diserahkan kepada distributor ataupun para agen yang ingin bekerja sama dengan Ide Kreatif.

\section{Aspek Pasar dan Pemasaran}

\section{Kondisi Saat Ini}

Saat ini, penulis yang menerbitkan bukunya melalui Ide Kreatif berjumlah 10 orang. Mayoritas klien Ide Kreatif ini berasal dari daerah-daerah yang ada di Jawa Timur. Mayoritas semua klien Ide Kreatif didapatkan dari informasi yang telah di-publish oleh manajemen Ide Kreatif di internet. Adapun dari 10 penulis tersebut, ada salah satu buku yang diusahakan Ide Kreatif untuk menyebar di seluruh Indonesia. Hingga saat ini, buku tersebut telah dibaca oleh 30 orang yang posisinya di berbagai wilayah Indonesia. 
Internet merupakan salah satu pemasaran yang dilakukan Ide Kreatif selama ini. Adapun pemasaran melalui internet dipilih dikarenakan orang yang berpeluang menjadi tahu dengan usaha bisnis dan produk yang ditawarkan oleh Ide Kreatif menjadi lebih banyak jika dibandingkan dengan usaha pemasaran lainnya. Hal inilah yang menjadi alasan bahwa manajemen Ide Kreatif menekankan pemasaran via internet (facebook dan twitter) mendapatkan porsi perhatian yang lebih besar jika dibandingkan dengan pemasaran yang dilakukan lainnya. Pemasaran lain yang dilakukan oleh Ide Kreatif selain melalui internet adalah dengan melakukan promosi secara personal kepada yang dikenal dan promosi melalui seminar. Dari ketiga kegiatan pemasaran yang dilakukan Ide Kreatif tersebut, pemasaran melalui internet memiliki peluang yang paling besar dalam mendatangkan klien dibandingkan dua kegiatan pemasaran yang dilakukan lainnya.

\section{Pembahasan}

Adapun pembahasan aspek pasar dan pemasaran dalam subbab ini akan dibagi menjadi 3 sesuai indikator yang telah ditentukan. Penjelasannya masingmasing sebagai berikut:

\section{SWOT (Strength. Weakness. Opportunities. Threats)}

Analisis SWOT ini merupakan sebuah analisis yang digunakan untuk mengetahui kekuatan, kelemahan, peluang, dan ancaman yang dimiliki oleh seseorang maupun sekelompok orang sehingga akan diketahui tentang strategi yang akan dipilih untuk mengatasinya. Dengan kata lain, dengan melakukan analisis SWOT, maka Ide Kreatif akan mampu menutupi 
kelemahan dan mengandalkan kekuatannya untuk mengatasi segala peluang dan ancaman yang dimiliki. Hasil yang diperoleh dari analisis SWOT akan mampu membantu Ide Kreatif dalam mengembangkan usaha bisnisnya.

Dalam penelitian ini, analisis SWOT dilakukan dengan cara menganalisis perusahaan-perusahaan yang menjadi kompetitor bisnis Ide Kreatif. Adapun kompetitor tersebut dapat dilihat pada Tabel 4.1. berikut.

Tabel 4.1.

Daftar Kompetitor Bisnis Ide Kreatif

\begin{tabular}{|c|c|c|}
\hline No. & Nama Kompetitor & Lokasi \\
\hline 1. & CV. Karya Utama & Kasuari 15 \\
\hline 2. & Victory Publishing & Simorukun 5 no 9AA \\
\hline 3. & UD. Galaxy & Tubanan Baru blok A-45 \\
\hline
\end{tabular}

Sumber: Observasi

Alasan dipilihnya ketiga kompetitor tersebut dikarenakan kompetitor tersebut berada di kota yang sama dengan Ide Kreatif dan ketiga kompetitor juga melakukan pengembangan bisnisnya. Hal ini menunjukkan bahwa penentuan sampel dilakukan dengan menggunakan metode purpossive sampling. yaitu sebuah metode pengambilan sampel berdasarkan kriteria tertentu yang telah ditetapkan peneliti. Dari ketiga kompetitor tersebut, akan dianalisis SWOT dengan melakukan wawancara dengan manajemen masing-masing perusahaan. Akan tetapi, dikarenakan kesulitan untuk mewawancarai pemilik dari masing-masing perusahaan tersebut, maka wawancara dilakukan terhadap karyawan masing-masing perusahaan kompetitor.

Adapun pedoman pertanyaan wawancara pada karyawan perusahaan kompetitor dapat dilihat pada Tabel 4.2. berikut, 
Tabel 4.2.

Pedoman Pertanyaan Wawancara Kompetitor

\begin{tabular}{|c|l|l|}
\hline No. & \multicolumn{1}{|c|}{ Pertanyaan } & \multicolumn{1}{c|}{ Tujuan } \\
\hline 1. & Jenis buku yang dijual & $\begin{array}{l}\text { Mengetahui jenis buku yang dijual } \\
\text { kompetitor }\end{array}$ \\
\hline 2. & $\begin{array}{l}\text { Jumlah judul buku yang } \\
\text { diproduksi }\end{array}$ & $\begin{array}{l}\text { Mengetahui jumlah permintaan judul } \\
\text { buku yang diproduksi di kompetitor }\end{array}$ \\
\hline 3. & Cara melakukan penjualan & Mengetahui cara penjualan kompetitor \\
\hline 4. & $\begin{array}{l}\text { Strategi pemasaran yang } \\
\text { dilakukan perusahaan }\end{array}$ & $\begin{array}{l}\text { Mengetahui strategi pemasaran yang } \\
\text { dilakukan kompetitor }\end{array}$ \\
\hline 5. & Omset penjualan per bulan & Mengetahui omset penjualan kompetitor \\
\hline
\end{tabular}

Sumber: Data Primer. diolah

Hasil wawancara yang dilakukan akan dibahas satu persatu dalam subbab ini. Pertanyaan pertama yaitu tentang jenis buku yang dijual masingmasing perusahaan. CV. Karya Utama menjual buku pelajaran, kamus, dan buku motivasi. Sementara Victory Publishing menjual buku motivasi, novel, dan buku pelajaran. Kemudian UD. Galaxy menjual buku pelajaran, novel, majalah, buku motivasi, dan Al-Qur'an. Dari jenis buku yang dijual tersebut, mampu memberi masukan bagi Ide Kreatif tentang buku apa yang harus dijual. Misalnya dari ketiga perusahaan tersebut, buku pelajaran dan buku motivasi merupakan dua pokok produk yang selalu ada. Secara umumpun, sebenarnya dua produk tersebut akan selalu ada di penerbitan ataupun toko buku manapun. Dengan demikian, Ide Kreatif harus tetap menjadikan dua produk tersebut selalu ada dalam tiap proses bisnis yang dijalankan. Hal ini untuk mendukung rencana pengembangan bisnis Ide Kreatif yang menginginkan untuk peningkatan penjualan produk yang telah diproduksi.

Selain kedua buku tersebut, Ide Kreatif juga harus menangkap peluang untuk penjualan novel dan buku-buku tentang agama. Hal ini dikarenakan saat ini novel dari kalangan anak-anak hingga dewasa telah mengalami pertumbuhan yang cukup signifikan. Hal ini tentu merupakan 
sebuah peluang yang tidak boleh dikesampingkan oleh manajemen. Selain novel, buku yang membahas tentang agama juga semakin populer akhir-akhir ini seiring dengan beberapa peristiwa menarik di negeri ini yang menyinggung masalah agama, salah satunya misal teroris. Dengan menangkap semua peluang yang ada, maka Ide Kreatif mampu mengembangkan bisnisnya dengan ide-ide inovatif.

Selanjutnya yaitu pertanyaan kedua tentang jumlah judul buku yang diproduksi dalam waktu satu semester. CV. Karya Utama memproduksi buku sebanyak kurang lebih 6 buku dalam kurun waktu satu semester. Jumlah tersebut merupakan yang paling banyak jika dibandingkan dengan Victory Publishing yang hanya memproduksi 4-5 judul buku dan UD. Galaxy yang memproduksi kurang lebih 4 buku dalam kurun waktu yang sama. Dari jumlah produksi buku tersebut dapat diambil kesimpulan bahwa 4 merupakan jumlah standar produksi buku dalam kurun waktu 6 bulan. Akan tetapi sebenarnya semua itu tergantung pada SDM (Sumber Daya Manusia) yang dimiliki oleh masing-masing perusahaan. Jika Ide Kreatif memiliki kualitas SDM yang bagus dan manajemen waktu yang baik dalam menjalankan usaha bisnis, maka jumlah produksi buku di atas standarpun tidak akan menjadi masalah. Hal ini harus ditangkap Ide Kreatif sebagai peluang dalam menjalankan usaha bisnisnya.

Lanjut ke pertanyaan ketiga wawancara tentang mekanisme penjualan yang dilakukan masing-masing perusahaan. Mekanisme penjualan yang dilakukan oleh CV. Karya Utama dan Victory Publishing sama, yaitu dengan melakukan penjualan langsung pada toko buku. Hal ini menunjukkan bahwa 
perusahaan merangkap sekaligus dua peran, sebagai produksi dan distributor. Hal ini berbeda dengan UD. Galaxy yang mekanisme penjualannya diberikan kepada distributor ataupun agen. Dari hal tersebut dapat dianalisis bahwa sebenarnya merangkap sebagai produksi dan distributor bukanlah hal yang susah. tapi juga tidak dapat dibilang mudah. Hal ini kembali lagi tergantung pada kualitas dan kesiapan masing-masing SDM yang dimiliki. Adapun rencana pengembangan bisnis yang akan dilakukan oleh Ide Kreatif adalah dengan memisahkan kedua peran tersebut, sehingga masalah mekanisme penjualan diserahkan kepada distributor ataupun agen. Hal ini bertujuan untuk fokus pada proses produksi. Walaupun pada praktiknya nanti. Ide Kreatif akan tetap memantau karena pengiriman produk dari Ide Kreatif ke distributor atau agen tetap menjadi tanggung jawab Ide Kreatif.

Pertanyaan selanjutnya yaitu tentang strategi pemasaran perusahaan. Dari ketiga perusahaan kompetitor, semuanya memiliki strategi pemasaran yang berbeda-beda. Pertama yaitu CV. Karya Utama yang melakukan pemasaran melalui facebook perusahaan, membangun jaringan dengan penulis-penulis besar, dan sering melakukan talk show di radio. Kemudian untuk Victory Publishing, strategi pemasaran yang dilakukan yaitu dengan memanfaatkan social media yang ada dan membangun jaringan dengan komunitas penulis. Sementara UD. Galaxy dengan menerapkan strategi sering mengadakan pameran di mall dan book fair yang ada di wilayah Jawa Timur. Berbagai strategi pemasaran tersebut dapat diadopsi dan diimplementasikan oleh Ide Kreatif. Tapi tetap harus ada sesuatu yang mampu membedakan mana strategi Ide Kreatif dan mana strategi kompetitor. Dengan hal yang 
membedakan itulah, yang akan membuat strategi pemasaran menjadi lebih unik dan mampu menarik perhatian khalayak.

Misalnya saja Ide Kreatif akan mengimplementasikan membangun jaringan dengan komunitas penulis. Adapun salah satu cara yang unik yaitu dengan melakukan ekspansi ke beberapa komunitas penulis dan kemudian mengadakan sebuah lomba. Lomba menulis cerita, flash fiction, puisi, dan lainnya memang hal yang lumrah. Tapi misal lomba menulis impian jadi penulis besar setelah menerbitkan buku di Ide Kreatif, hal ini jarang dilakukan. Dengan mulai mengikuti lomba tersebut, maka secara tidak langsung penulis akan mulai bermimpi dan Ide Kreatif menjadi salah satu pihak yang berkepentingan dalam mimpi tersebut. Hal ini akan membuat semua penulis yang ada dalam komunitas penulis manapun mengetahui keberadaan Ide Kreatif sebagai salah satu penerbit yang bisa menerbitkan bukunya, sehingga akan berdampak positif pada Ide Kreatif.

Apalagi sejalan dengan rencana pengembangan bisnis yang akan dilakukan, dimana Ide Kreatif akan membeli karya penulis dan akan mencetaknya dalam bentuk buku. Kemudian buku tersebut akan disebarkan ke seluruh wilayah Indonesia. Dalam hal ini, penulis tidak akan mengeluarkan uang sepeserpun, karena Ide Kreatif yang akan menanggung semua biaya percetakan, penerbitan, hingga pendistribusian produk. Penulis disini malah akan mendapatkan royalti dari hasil karyanya. Dengan demikian, hal ini akan memberikan keuntungan bagi kedua pihak. Dari pihak penulis akan diuntungkan karena naskahnya dibeli dan dibayar dengan royalti dari 
hasil karyanya. Sementara dari pihak Ide Kreatif, akan diuntungkan dengan hasil penjualan produk tersebut.

Kemudian untuk pertanyaan wawancara terakhir pada perusahaan kompetitor yaitu tentang omset penjualan per bulan. Dari ketiga kompetitor tersebut, omset penjualan paling tinggi yaitu CV. Karya Utama yaitu dengan omset kurang lebih antara Rp 150.000.000.00 - Rp 200.000.000.00. Sementara omset Victory Publishing kurang lebih antara Rp 85.000.000.00 Rp 145.000.000.00 dan omset UD. Galaxy berkisar kurang lebih dari Rp 120.000.000.00. Dari omset penjualan tersebut, maka Ide Kreatif harus memberi perhatian lebih pada CV. Karya Utama dengan menganalisis usaha yang dilakukan sehingga mampu mendapatkan omset yang lumayan besar. Akan tetapi perhatian pada Victory Publishing dan UD. Galaxy tidak boleh dibuang, karena bagaimanapun juga setiap perusahaan memiliki kelebihan dan keunikan masing-masing. Dengan kelebihan dan keunikan itulah yang akan menjadikan perusahaan dikenal oleh khalayak. Ide Kreatif sendiri juga memiliki target tersendiri dalam omset penjualan ini. Hal ini dikarenakan omset penjualan yang meningkat akan membuat arus kas menjadi stabil. Dengan demikian, maka rencana pengembangan usaha bisnis akan dapat dilakukan dengan cepat. Mulai dari perbaikan kualitas SDM hingga perbaikan pendapatan yang diterima oleh perusahaan.

Dari semua pertanyaan dan jawaban hasil wawancara tersebut dapat diringkas dalam Tabel 4.3. berikut, 
Tabel 4.3.

Ringkasan Hasil Wawancara dengan Perusahaan Kompetitor

\begin{tabular}{|c|l|l|l|l|}
\hline No. & \multicolumn{1}{|c|}{$\begin{array}{c}\text { Objek } \\
\text { Pertanyaan }\end{array}$} & CV. Karya Utama & \multicolumn{1}{c|}{$\begin{array}{c}\text { Victory } \\
\text { Publishing }\end{array}$} & \multicolumn{1}{|c|}{ UD. Galaxy } \\
\hline 1. & $\begin{array}{l}\text { Jenis buku yang } \\
\text { dijual }\end{array}$ & $\begin{array}{l}\text { Buku pelajaran, } \\
\text { kamus, dan buku } \\
\text { motivasi }\end{array}$ & $\begin{array}{l}\text { Buku motivasi, } \\
\text { novel, dan buku } \\
\text { pelajaran }\end{array}$ & $\begin{array}{l}\text { Buku pelajaran, } \\
\text { novel, majalah, } \\
\text { motivasi, dan } \\
\text { Al-Quran. }\end{array}$ \\
\hline 2. & $\begin{array}{l}\text { Jumlah judul buku } \\
\text { yang diproduksi }\end{array}$ & $\begin{array}{l}\text { Satu semester } \\
\text { kurang lebih 6 judul } \\
\text { buku }\end{array}$ & $\begin{array}{l}\text { Satu semester } \\
\text { kurang lebih 4- } \\
\text { 5 judul buku }\end{array}$ & $\begin{array}{l}\text { Satu semester } \\
\text { kurang lebih } \\
\text { kurang lebih 4 } \\
\text { buku }\end{array}$ \\
\hline 3. & $\begin{array}{l}\text { Penjualan } \\
\text { perusahaan }\end{array}$ & $\begin{array}{l}\text { Penjualan langsung } \\
\text { ke toko buku dan } \\
\text { perusahaan ini } \\
\text { merangkap sebagai } \\
\text { distributor }\end{array}$ & $\begin{array}{l}\text { Penjualan } \\
\text { langsung ke } \\
\text { toko buku dan } \\
\text { perusahaan ini } \\
\text { merangkap } \\
\text { sebagai } \\
\text { distributor }\end{array}$ & $\begin{array}{l}\text { Penjualan } \\
\text { melalui } \\
\text { distributor atau } \\
\text { agen }\end{array}$ \\
\hline 4. & $\begin{array}{l}\text { Strategi pemasaran } \\
\text { perusahaan }\end{array}$ & $\begin{array}{l}\text { Facebook } \\
\text { perusahaan dan } \\
\text { menjaring penulis- } \\
\text { penulis besar. sering } \\
\text { melakukan } \\
\text { talkshow di radio }\end{array}$ & $\begin{array}{l}\text { Melalui social } \\
\text { media dan } \\
\text { menjaring } \\
\text { penulis dari } \\
\text { komunitas. }\end{array}$ & $\begin{array}{l}\text { Mengadakan } \\
\text { pameran di mal } \\
\text { dan book fair di } \\
\text { wilayah jawa } \\
\text { timur }\end{array}$ \\
\hline 5. & $\begin{array}{l}\text { Omarang lebih Rp } \\
\text { Rp. 150.000.000- } \\
\text { Rp. 200.000.000 }\end{array}$ & $\begin{array}{l}\text { Kurang lebih } \\
\text { Rp. 85.000.000- } \\
\text { Rp. 145.000.000 }\end{array}$ & $\begin{array}{l}\text { Kurang lebih Rp } \\
\text { 120.000.000 }\end{array}$ \\
\hline
\end{tabular}

Sumber: Data Primer. diolah

Setelah melakukan wawancara pada karyawan yang berada di masingmasing perusahaan kompetitor, dilakukan observasi secara langsung. Observasi dilakukan untuk menambah informasi tentang kondisi kompetitor. Adapun hasil observasi dapat dilihat pada Tabel 4.4. dengan melihat kekuatan dan kelemahan dari masing-masing perusahaan kompetitor tersebut. 
Tabel 4.4.

Rangkuman Hasil Observasi Pada Perusahaan Kompetitor

\begin{tabular}{|c|c|c|c|}
\hline No. & $\begin{array}{c}\text { Nama } \\
\text { Kompetitor }\end{array}$ & Kekuatan & Kelemahan \\
\hline 1. & CV. Karya Utama & $\begin{array}{l}\text { - Memiliki peralatan } \\
\text { yang lengkap } \\
\text { - Memiliki armada } \\
\text { penjualan luar pulau } \\
\text { - Jaringan penjualan } \\
\text { luas } \\
\text { - Desain buku yang } \\
\text { dimiliki sangat } \\
\text { mearik } \\
\text { - Kualitas kertas yang } \\
\text { digunakan cukup } \\
\text { bagus } \\
\text { - Memiliki nama besar } \\
\text { di Surabaya }\end{array}$ & $\begin{array}{l}\text { - Harga vahan dari } \\
\text { suplier masih } \\
\text { terlalu mahal } \\
\text { - Judul buku yang } \\
\text { diproduksi terbatas }\end{array}$ \\
\hline 2. & $\begin{array}{l}\text { Victory } \\
\text { Publishing }\end{array}$ & $\begin{array}{l}\text { - Memiliki relasi di } \\
\text { komunitas penulis } \\
\text { - Kualitas buku yang } \\
\text { diproduksi cukup } \\
\text { bagus } \\
\text { - Memiliki armada } \\
\text { penjualan luar pulau }\end{array}$ & $\begin{array}{l}\text { - Judul buku yang } \\
\text { dijual terbatas } \\
\text { - Pegawai terbatas } \\
\text { sehingga setiap } \\
\text { karyawan memiliki } \\
\text { tugas ganda. }\end{array}$ \\
\hline 3. & UD. Galaxy & $\begin{array}{l}\text { - Desain buku yang } \\
\text { simpel } \\
\text { - Peralatan cukup } \\
\text { lengkap }\end{array}$ & $\begin{array}{l}\text { - Tidak memiliki } \\
\text { armada penjualan } \\
\text { luar pulau } \\
\text { - Sering mengalami } \\
\text { buku cacat hampir } \\
5 \% \\
\text { - Judul buku yang } \\
\text { dijual terbatas }\end{array}$ \\
\hline
\end{tabular}

Sumber: Data Primer. diolah

Dari Tabel 4.4. di atas dapat dilihat bahwa hampir semua perusahaan kompetitor memiliki kekuatan dan kelemahan. Hal ini menjadi unik karena akan membedakan satu perusahaan dengan perusahaan lainnya. Misalnya saja CV. Karya Utama yang memiliki paling banyak kekuatan, sebanyak apapun kekuatan yang dimiliki, pasti ada juga kelemahan yang dimiliki. Dikarenakan kelemahan itulah yang membuat perusahaan terus berkembang. 
Dari berbagai uraian di atas tentang analisis SWOT, maka selanjutnya akan melakukan analisis SWOT pada Ide Kreatif itu sendiri. Pertama akan dianalisis tentang unsur S (Strength). Adapun beberapa poin kekuatan yang dimiliki oleh Ide Kreatif antara lain: melayani penulis yang ingin menerbitkan bukunya dimana hal ini menjadi satu kekuatan untuk menarik pelanggan lebih banyak sehingga harus tetap dipertahankan walaupun Ide Kreatif tetap memiliki kualifikasi tersendiri pada naskah yang akan diterbitkan, memiliki jaringan yang bagus di dunia maya dikarenakan pemasaran melalui internet yang dilakukan oleh Ide Kreatif, pemasaran personal dilakukan oleh semua SDM yang ada dikarenakan prinsip Ide Kreatif adalah semua orang yang ada merupakan seorang marketer sehingga harus terus melakukan kegiatan pemasaran jika mempunyai sebuah kesempatan, serta memiliki sebuah kantor sendiri sehingga memiliki tempat pasti yang akan dituju oleh calon pelanggan. Selanjutnya pembahasan pada unsur kedua. yaitu unsur W (Weakness). Ide Kreatif juga memiliki beberapa kelemahan, antara lain: pemasaran dilakukan tidak dalam porsi utama karena tidak ada SDM yang menangani khusus untuk pemasaran, pangsa pasar penulis yang masih terlalu luas karena belum menentukan target yang ingin dicapai, dan kurangnya pengalaman SDM dalam melakukan pemasaran sehingga perlu lebih banyak belajar tentang bagaimana melakukan sebuah pemasaran.

Setelah unsur S dan W ditentukan, maka selanjutnya menganalisis unsur O (Opportunities) atau peluang. Ide Kreatif memiliki beberapa peluang bisnis, antara lain: kompetitor yang masih belum menjamur sehingga Ide Kreatif memiliki waktu untuk terus mengembangkan bisnisnya sebelum 
kompetitor lebih banyak lagi, minat baca masyarakat yang cenderung meningkat walaupun hanya pada kalangan tertentu, dan keunggulan buku yang belum mampu tergeser oleh apapun walaupun saat ini $e$-book sudah mulai banyak beredar. Selain peluang, Ide Kreatif juga menghadapi ancaman yang dimungkinkan akan dapat mengganggu eksistensi usaha bisnis Ide Kreatif. Adapun unsur $\mathrm{T}$ (Threats) yang dimiliki Ide Kreatif antara lain: dengan meningkatnya berbagai unsur yang akhirnya menjadikan usaha bisnis penerbitan menggiurkan maka akan semakin banyak bermunculan kompetitor-kompetitor yang lain dan strategi pemasaran juga tidak dapat dipatenkan untuk selamanya melainkan harus selalu mengikuti perkembangan pasar.

Dari keseluruhan wawancara tersebut, maka selanjutnya yaitu dianalisis menggunakan tabel perhitungan pembobotan sebagai berikut.

Tabel 4.5.

Perhitungan Bobot SW (Strength Weakness)

\begin{tabular}{|l|l|c|c|c|}
\hline No & \multicolumn{1}{|c|}{ Strengths } & Skor & Bobot & Total \\
\hline 1. & Melayani semua penulis. & 9 & $30 \%$ & 2,7 \\
\hline 2. & $\begin{array}{l}\text { Memiliki jaringan yang bagus di } \\
\text { dunia maya. }\end{array}$ & 8 & $25 \%$ & 2 \\
\hline 3. & $\begin{array}{l}\text { Pemasaran dilakukan semua } \\
\text { SDM yang ada. }\end{array}$ & 6 & $25 \%$ & 1,5 \\
\hline 4. & Memiliki kantor sendiri. & 7 & $20 \%$ & 1,4 \\
\hline \multicolumn{1}{|c|}{ Total Strength Weakness } & Skor & Bobot & Total \\
\hline No & \multicolumn{1}{|c|}{$\begin{array}{l}\text { Temasaran dilakukan tidak } \\
\text { dalam porsi utama. }\end{array}$} & $80 \%$ & 3,2 \\
\hline 1. & $\begin{array}{l}\text { Pangsa pasar penulis masih } \\
\text { terlalu luas. }\end{array}$ & 7 & $30 \%$ & 2,1 \\
\hline 3. & $\begin{array}{l}\text { Kurangnya SDM yang } \\
\text { melakukan pemasaran. }\end{array}$ & 7 & 2,1 \\
\hline \multicolumn{2}{|c|}{ Total Weakness } \\
\hline
\end{tabular}

Sumber: Data Primer. diolah 
Kemudian berdasarkan wawancara yang dilakukan dengan pesaing. juga akan dianalisis dalam tabel pembobotan seperti berikut,

Tabel 4.6.

Perhitungan Bobot OT (Opportunities Threats)

\begin{tabular}{|l|l|c|c|c|}
\hline No & \multicolumn{1}{|c|}{ Opportunities } & Skor & Bobot & Total \\
\hline 1. & $\begin{array}{l}\text { Kompetitor yang masih belum } \\
\text { menjamur. }\end{array}$ & 7 & $30 \%$ & 2,1 \\
\hline 2. & $\begin{array}{l}\text { Minat baca masyarakat } \\
\text { cenderung meningkat. }\end{array}$ & 8 & $30 \%$ & 2,4 \\
\hline 3. & $\begin{array}{l}\text { Buku belum mampu digeser } \\
\text { olehe-book. }\end{array}$ & 8 & $40 \%$ & 3,2 \\
\hline \multicolumn{1}{|c|}{ Total Opportunities } & Skreats & Bobot & Total \\
\hline No & \multicolumn{1}{|c|}{ bertumbuhnya } & 8 & 4 \\
\hline 1. & $\begin{array}{l}\text { Potensial } \\
\text { kompetitor. }\end{array}$ & $50 \%$ & 3,5 \\
\hline 2. & $\begin{array}{l}\text { Strategi pemasaran yang tidak } \\
\text { digunakan selamanya. }\end{array}$ & 7 & $\mathbf{7 , 5}$ \\
\hline \multicolumn{2}{|c|}{ Total Threats } \\
\hline
\end{tabular}

Sumber: Data Primer. Diolah

Berdasarkan dari tabel perhitungan bobot SW dan OT di atas. maka dibuat

posisi perusahaan Ide Kreatif dalam matriks SWOT sebagai berikut.

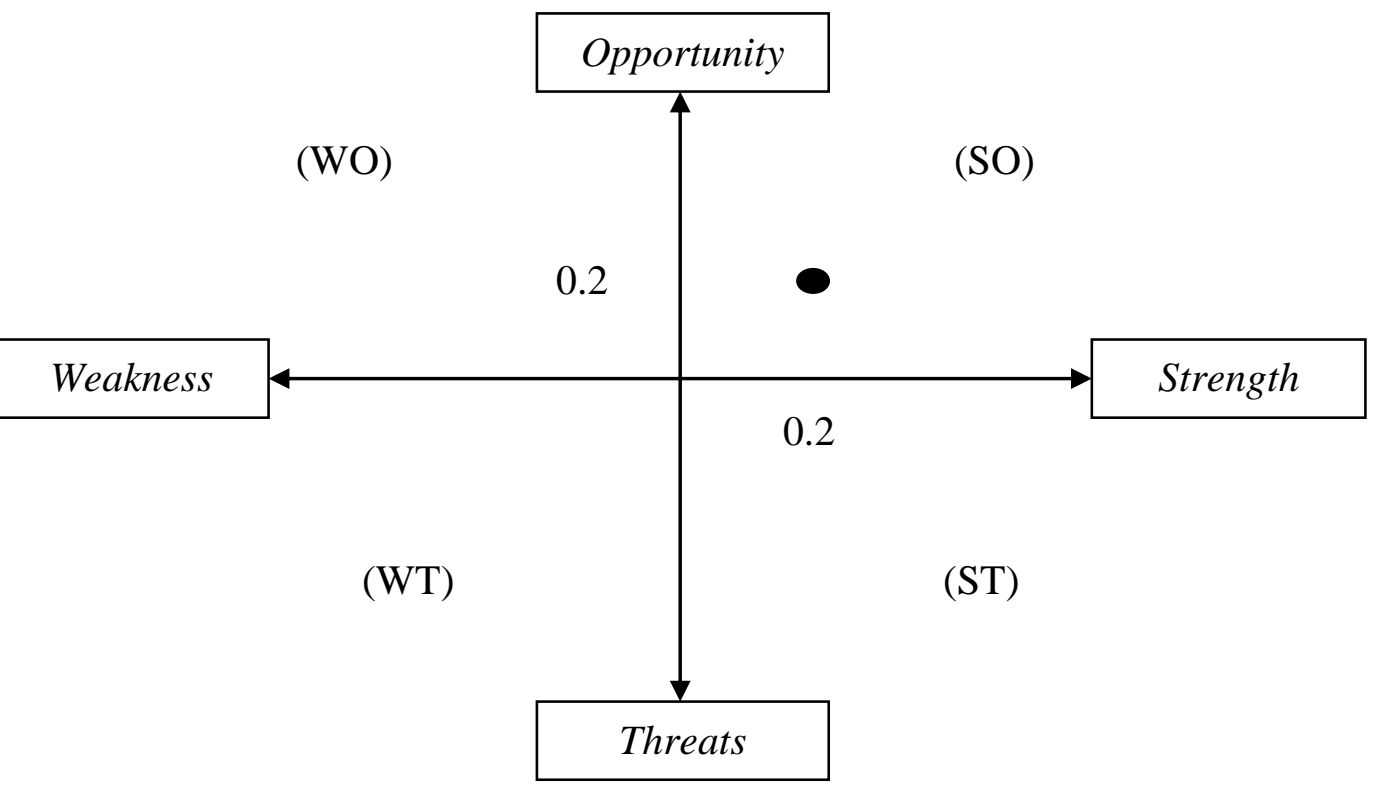

Gambar 4.1.

Matriks Kuadran SWOT Ide Kreatif

Sumber: Data Primer, diolah 
Dari Gambar 4.1. di atas menunjukkan bahwa posisi kuadran matriks SWOT Ide Kreatif berada pada kuadran satu (SO). Menurut Umar (2009: 230), posisi di kuadran 1 (satu) merupakan situasi yang sangat menguntungkan. Hal ini dikarenakan perusahaan memiliki peluang dan kekuatan sehingga dapat memanfaatkan peluang yang ada. Adapun strategi pemasaran yang ditetapkan dalam kondisi ini adalah strategi yang mendukung kebijakan pertumbuhan yang agresif. Dengan demikian, strategi pertumbuhan yang akan dilakukan Ide Kreatif antara lain:

a. Mencetak segala jenis buku yang memiliki peluang dapat menguasai pasar. misalnya buku motivasi, buku agama, buku novel, buku anakanak, buku biografi, buku pelajaran, dan buku nonfiksi.

b. Menambah jaringan ke penulis maupun calon penulis yang ada di seluruh Indonesia baik melalui dunia maya maupun membuat perwakilan utusan tiap-tiap daerah.

c. Meneruskan ekspansi pemasaran jasa dan produk ke seluruh wilayah Indonesia. tanpa terkecuali dengan porsi lebih besar melalui internet.

d. Menyalurkan produk yang telah dihasilkan kepada agen maupun distributor di seluruh Indonesia.

e. Meningkatkan kinerja karyawan secara bertahap.

Kemudian untuk taktik yang akan dilakukan. antara lain:

a. Memberi bonus bagi karyawan yang mampu memberikan kinerja di atas standar.

b. Menambah intensitas pengadaan lomba bagi calon penulis untuk menjaring naskah dengan kualitas yang bagus. 
c. Melakukan talkshow di radio dan memberikan kartu nama kepada setiap orang yang dikenal dan ditemui.

Dengan melakukan berbagai strategi tersebut. diharapkan tujuan Ide Kreatif akan dapat tercapai.

\section{STP (Segmenting. Targetting. Positioning)}

Untuk indikator STP ini akan dijelaskan pada masing-masing unsur yang menyusun STP itu sebagai berikut:

a. Segmenting

Segmentasi yang akan dilakukan dalam penelitian ini berasal dari 3 hal. yaitu segmentasi geografi, segmentasi demografi, dan segmentasi psikografi. Dengan adanya ketiga segmentasi tersebut, maka diharapkan akan mampu memperbaiki aspek pasar dan pemasaran Ide Kreatif. Adapun penjelasan masing-masing segmentasi sebagai berikut:

1) Segmentasi geografi

Segmentasi disini merupakan pembagian pasar menjadi unit-unit geografi yang berbeda dengan tujuan untuk memperoleh kepastian kemana atau dimana pemasaran Ide Kreatif akan dilaksanakan. Menurut analisis dari komunitas penulis selama ini. penulis dan pembaca tersebar di hampir seluruh wilayah Indonesia. Dengan demikian, Ide Kreatif membagi pasar menjadi 2 bagian. yaitu wilayah Indonesia Timur dan Indonesia Barat. Adapun selama ini, penjualan terbanyak ada di Indonesia Timur, hal ini yang menjadikan alasan Ide Kreatif akan menguasai wilayah 
Indonesia Timur. Namun tetap ekspansi ke wilayah Indonesia Barat terus dilakukan.

2) Segmentasi demografi

Segmentasi demografi menggambarkan tentang kondisi pasar yang akan dituju berdasarkan pada umur, jenis kelamin, jumlah anggota keluarga, siklus kehidupan keluarga, kawin atau belum kawin, jumlah anak dalam keluarga, dan seterusnya. Segmentasi demografi Ide Kreatif akan dibedakan berdasarkan pada umur, jenis kelamin, siklus kehidupan keluarga, dan kawin atau belum kawin. Dengan berbagai indikator demografi tersebut akan dapat diketahui mana pasar yang memiliki potensial untuk ditawari jasa dan produk yang ditawarkan Ide Kreatif.

3) Segmentasi psikografi

Segmentasi psikografi merupakan sebuah aktivitas pembagian kelompok atau segmen berdasarkan status sosial, gaya hidup, dan kepribadian. Status sosial yang dimaksud disini yaitu statusnya di masyarakat maupun di lingkungan tempatnya beraktivitas sehari-hari. Kemudian untuk gaya hidup, dapat dilihat dari gaya hidup hedonis ataukah sederhana. Sementara kepribadian dapat dilihat dari 4 hal, antara lain: sanguinis (banyak bicara, populer), melankolis (pemikir, idealis), koleris (kuat, pelaku), dan plegmatis (damai, pengamat). Dengan berbagai segmentasi psikografi tersebut, maka akan dapat diketahui potensi pasar terletak di tipe psikografi yang bagaimana. 


\section{b. Targetting}

Adapun target yang dimiliki oleh Ide Kreatif adalah penulis besar dan calon penulis besar yang ada di Indonesia untuk penawaran jasa penerbitan, seluruh elemen masyarakat mulai dari anak-anak, remaja, hingga dewasa yang ada di seluruh Indonesia untuk penawaran produk yang telah diterbitkan. Target pertama penawaran jasa yaitu penulis besar. Hal ini dilakukan karena jika ada minimal satu saja penulis besar yang menjadi pelanggan Ide Kreatif dan dirinya puas, maka secara tidak langsung dirinya akan mempromosikan Ide Kreatif pada teman-teman dan semua orang yang dijumpainya jika memiliki kesempatan. Hal ini tentu akan memberikan dampak yang luar biasa positif bagi Ide Kreatif.

Target kedua penawaran jasa yaitu calon penulis besar yang dapat ditemukan di berbagai lomba. Calon penulis besar ini akan mampu dan memiliki kekuatan untuk mengikuti berbagai lomba penulisan yang ada. Apapun hasilnya, dirinya akan tetap ikut selanjutnya dan selanjutnya. Hal inilah yang dinamakan sebuah indikasi bahwa dirinya adalah calon penulis besar, dimana tidak ada rasa putus asa pada dirinya sehingga dirinya akan mencoba terus sampai kapanpun.

Kemudian untuk penawaran produk, target Ide Kreatif adalah masyarakat dari segala kalangan mulai dari anak-anak, remaja, dan dewasa. Hal ini dikarenakan produk yang akan diterbitkan oleh Ide Kreatif juga akan beraneka ragam, hingga nanti akan disesuaikan. 
Misalnya buku novel khusus untuk remaja, buku tentang pendidikan anak di usia dini dan buku motivasi dikhususkan untuk dewasa, dan buku dongeng untuk anak-anak. Semua target tersebut harus ditentukan, dengan kata lain antara produk dan konsumen harus disesuaikan terlebih dahulu. Hal ini menuntut keahlian manajemen Ide Kreatif dalam menganalisis pasar agar dapat meningkatkan penjualan produk yang telah diterbitkan.

c. Positioning

Untuk positioning. penulis ingin memposisikan Ide Kreatif sebagai penerbit yang merupakan sahabat para penulis dengan pelayanan dan kualitas terbaik. Hal ini dikarenakan Ide Kreatif belum memiliki posisi yang khusus di mata masyarakat. Dengan keinginan untuk memosisikan diri sebagai sahabat para penulis, maka manajemen Ide Kreatif menginginkan jika ada penulis yang mengalami masalah pada penerbitan, maka rujukan pertama ialah Ide Kreatif. Setelah menjadi sahabat, maka selanjutnya yaitu dengan memberikan kualitas dan pelayanan terbaik dibandingkan penerbit lainnya.

Kualitas terbaik juga akan berdampak pada konsumen yang membaca produk percetakan Ide Kreatif. Dengan kualitas warna. desain. kertas. dan unsur-unsur lain yang bagus, maka akan menjadi hal yang menarik bagi para konsumen untuk membeli produk tersebut. Apalagi jika didukung dengan naskah yang bermutu. Hal ini akan mampu memposisikan Ide Kreatif sebagai penerbit yang menjadi 
sahabat penulis dan penerbit yang memiliki produk dengan kualitas baik yang mampu menarik konsumen pembaca.

\section{Marketing Mix (4P: Product. Price. Place. Promotion)}

Indikator selanjutnya yaitu marketing mix yang terdiri dari 4 unsur dengan penjelasan masing-masing sebagai berikut:

a. Product (Produk)

Produk yang dihasilkan oleh Ide Kreatif berbentuk sebuah buku hasil karya penulis. Buku tersebut akan diterbitkan dan didistribusikan ke toko-toko buku di Indonesia oleh Ide Kreatif. Adapun produk tersebut dapat dilihat pada Gambar 4.2. berikut.
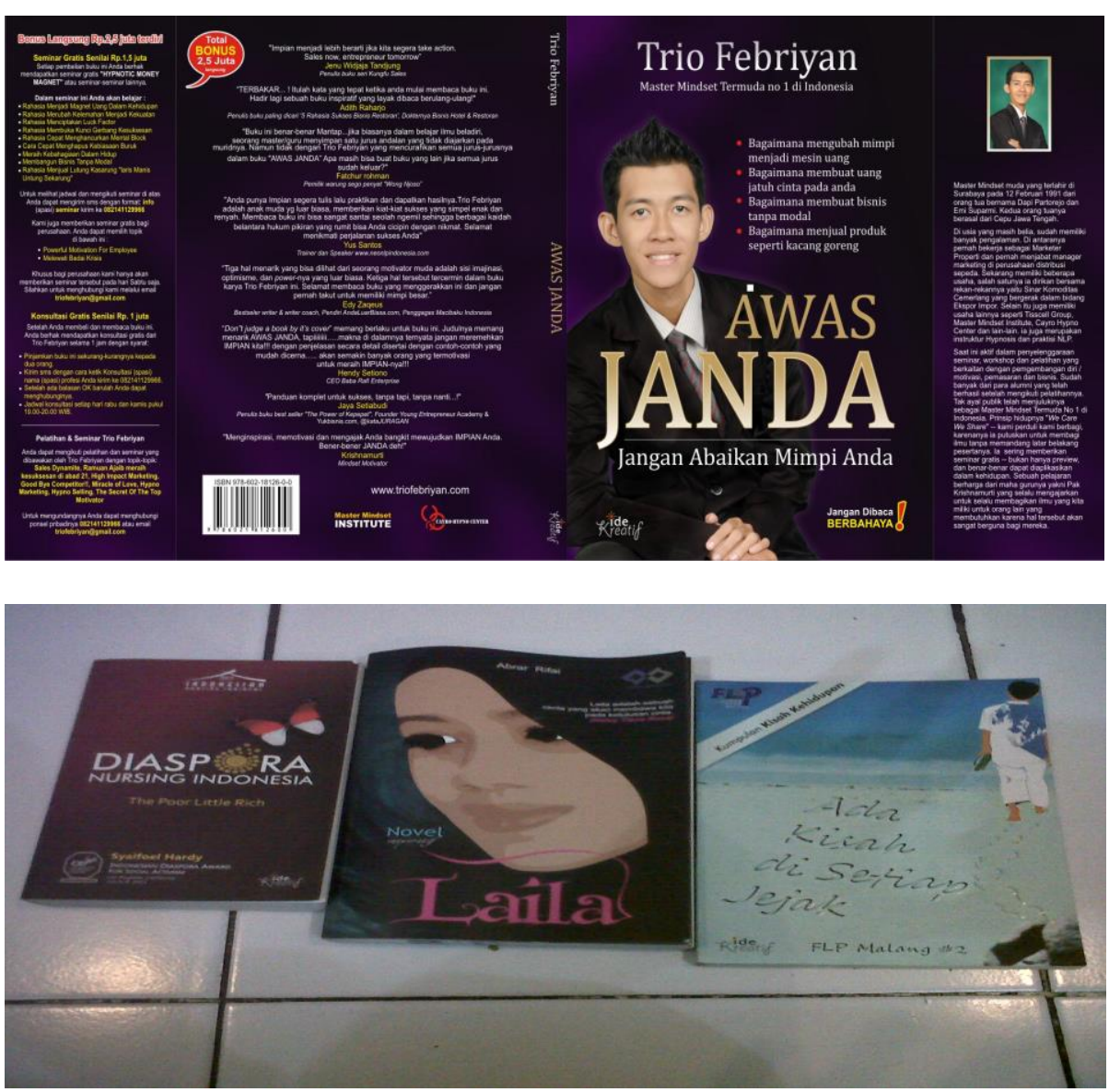

Gambar 4.2.

Produk-Produk Ide Kreatif

Sumber: Data Primer 
Dengan beberapa produk seperti pada Gambar 4.2. di atas, Ide Kreatif merencanakan perkembangan bisnis bahwa akan banyak buku lagi yang dihasilkan oleh Ide Kreatif. Jadi bukan hanya tentang buku motivasi dan novel. namun selanjutnya ada beberapa buku yang membahas tentang agama, buku pelajaran, biografi, dan macam buku lainnya. Akan tetapi buku motivasi dan buku novel juga akan tetap menjadi produk Ide Kreatif. Dengan proyeksi produk tersebut, maka manajemen Ide Kreatif harus segera memperbaiki segala unsur yang ada dalam perusahaan tersebut.

Selain produk tersebut, Ide Kreatif juga berencana ingin meningkatkan kualitas produk dan pelayanan kepada pelanggan. Hal ini dapat dilakukan dengan kemampuan Ide Kreatif dalam memberikan produk sesuai yang diinginkan oleh pelanggan. Mulai dari model, ketebalan, warna, jenis kertas, isi naskah, kualitas naskah, dan lainnya. Hal ini juga akan mampu menjadi daya tarik tersendiri dan merupakan keunggulan yang akan dimiliki Ide Kreatif.

b. Price

Dalam hal ini, manajemen Ide Kreatif menggunakan strategi harga yang akan berpengaruh pada tertariknya penulis untuk menerbitkan bukunya di Ide Kreatif. Penentuan harga Ide Kreatif berasal dari observasi dan analisis pasar selama ini dengan melihat harga kompetitor. Adapun rincian harga produk dapat dilihat pada Tabel 4.5. berikut. 
Tabel 4.5.

Daftar Harga Produk Ide Kreatif

\begin{tabular}{|l|l|l|c|}
\hline No & \multicolumn{1}{|c|}{ Jenis Produk } & $\begin{array}{c}\text { Harga Ide Kreatif } \\
(\text { Rp) }\end{array}$ & $\begin{array}{c}\text { Harga Penerbit Lain } \\
\text { (Rp) }\end{array}$ \\
\hline 1. & Buku motivasi & $50.000-100.000$ & $50.000-200.000$ \\
\hline 2. & Buku novel & $25.000-75.000$ & $30.000-100.000$ \\
\hline 3. & Buku nonfiksi & $30.000-100.000$ & $50.000-200.000$ \\
\hline
\end{tabular}

Sumber: Data Primer. diolah

Dari Tabel 4.5. tersebut dapat dilihat bahwa dari berbagai jenis produk yang ditawarkan oleh Ide Kreatif. harga yang ditawarkan relatif lebih rendah dibandingkan dengan harga yang diterapkan pada penerbit lain. Dengan demikian, harga yang ditetapkan Ide Kreatif memiliki harga bersaing dengan para kompetitor. Hal ini menunjukkan bahwa harga juga merupakan salah satu strategi pemasaran yang diimplementasikan oleh Ide Kreatif. Hal ini dikarenakan harga juga mampu memberi magnet tersendiri yang akan mampu menarik para pelanggan berdatangan. Akan tetapi juga tidak mungkin ketika harga sudah mampu menarik, kemudian kualitas penerbitan kalah dengan yang lain. Hal ini harus dicermati oleh manajemen Ide Kreatif agar dapat meningkatkan eksistensi.

c. Place

Tempat disini dilihat dari keberadaan kantor yang dimiliki Ide Kreatif di tempat yang mudah dijangkau, mudah ditemukan, dan mudah diakses dengan kendaraan apapun. Dengan lokasi kantor yang dapat digambarkan seperti itu, maka perusahaan akan menjadi daya tarik tersendiri bagi konsumen maupun calon konsumen yang ada.

Begitu pula dengan Ide Kreatif yang memiliki kantor di daerah Rungkut. Wilayah Rungkut termasuk wilayah Surabaya Selatan yang 
berbatasan langsung dengan Kabupaten Sidoarjo, hal ini membuat kesulitan dalam akses dan jangkauan oleh orang lain dari wilayah manapun. Apalagi wilayah Rungkut terkenal dengan kemacetannya karena memiliki banyak daerah industri dan perumahan. Hal ini akan merugikan nilai jual Ide Kreatif di mata konsumen.

Dengan alasan tersebut, maka manajemen Ide Kreatif harus memindahkan kantornya ke wilayah yang lebih menguntungkan untuk meningkatkan nilai jual Ide Kreatif itu sendiri. Selain itu, perpindahan kantor juga dapat dipertimbangkan sebagai salah satu cara untuk mendukung rencana pengembangan bisnis yang akan dilakukan Ide Kreatif. Dengan demikian, manajemen memutuskan untuk proyeksi ke depannya. Ide Kreatif akan memindahkan kantornya dari wilayah Rungkut ke wilayah Karah. Adapun lokasi proyeksi kantor daerah Karah dapat dilihat pada Gambar 4.3. berikut.

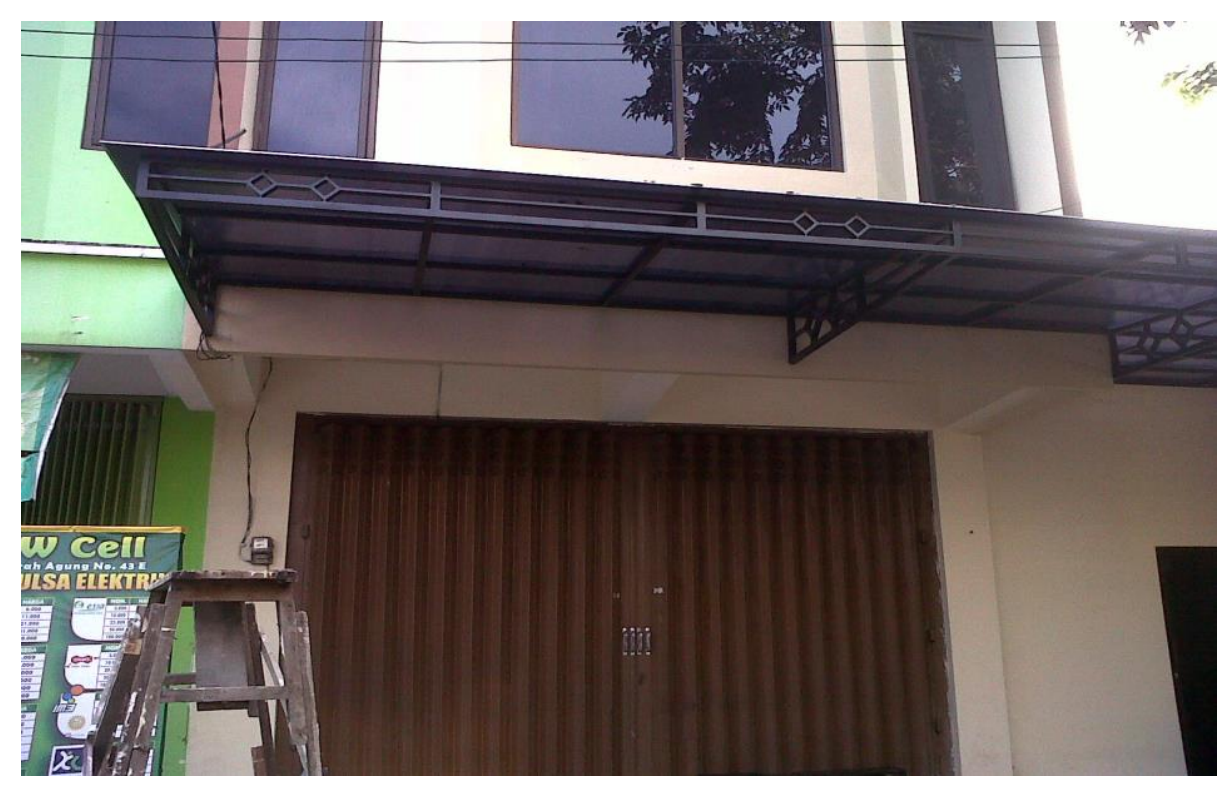

Gambar 4.3.

Lokasi Kantor Ide Kreatif di Surabaya Sumber: Data Primer. diolah 
Lokasi kantor sesuai Gambar 4.3. di atas berada di wilayah Karah yang relatif lebih mudah dijangkau dari kota Surabaya maupun dari Sidoarjo. Hal ini tentu akan meningkatkan nilai jual Ide Kreatif. sehingga pemasaran akan lebih mudah dilakukan.

\section{d. Promotion}

Promosi yang dilakukan Ide Kreatif melalui tiga cara. yaitu melalui internet, personal selling, dan pengumuman di acara seminar. Pemasaran internet dilakukan dengan melakukan pemasaran melalui facebook dan twitter. Pemasaran ini mendapatkan perhatian yang lebih dikarenakan dari pemasaran inilah yang mampu menarik pelanggan paling potensial. Hal ini dikarenakan cakupan pangsa wilayah pemasaran melalui internet merupakan paling besar jika dibandingkan dengan pemasaran melalui personal selling dan mempublikasikan diri di acara-acara seminar.

Untuk ke depannya, manajemen Ide Kreatif menginginkan peningkatan pemasaran melalui internet yang membuat pelanggan dan calon pelanggan untuk mengakses lebih cepat, lebih detail, dan lebih akurat. Adapun proyeksi pemasaran melalui internet ke depannya yaitu dengan membuat sebuah website resmi Ide Kreatif. Dari website itulah semua orang akan dapat melihat jasa dan produk yang ditawarkan Ide Kreatif, cara menghubungi Ide Kreatif. dan semua hal yang diperlukan penulis agar dapat menerbitkan bukunya Ide Kreatif. Hal ini diprediksi akan mampu menarik penulis lebih banyak untuk menerbitkan bukunya 
di Ide Kreatif dan mampu meningkatkan volume penjualan dari buku hasil terbitan Ide Kreatif.

\section{Kriteria Kelayakan}

Kriteria kelayakan pada aspek pasar dan pemasaran ini dapat ditinjau dari 3 indikator. antara lain analisis SWOT, STP, dan marketing mix. Pertama akan dibahas kriteria kelayakan dari analisis SWOT. Ide Kreatif dapat dikatakan layak jika posisi strategi yang dihasilkan dari matriks SWOT berada di posisi pertama dengan strategi agresif atau posisi kuadran kedua dengan strategi diferensiasi. Menurut analisis matriks SWOT pada Gambar 4.1. dapat dilihat bahwa posisi strategi yang dimiliki Ide Kreatif berada pada kuadran 1. Hal ini menunjukkan bahwa Ide Kreatif mampu melakukan rencana pengembangan bisnis dengan mengimplementasikan strategi agresif agar tujuan perusahaan dapat dicapai. Adapun strategi agresif itu dilakukan dikarenakan peluang yang dimiliki Ide Kreatif lebih besar dari ancaman yang dimiliki. Selain itu, penangkapan peluang akan lebih besar kesempatannya karena didukung dengan kekuatan yang dimiliki Ide Kreatif. Dengan demikian, strategi agresif diperlukan pada usaha bisnis ini.

Jika ditinjau dari indikator kedua tentang STP, Ide Kreatif dikatakan layak jika mampu menetapkan segmentasi berdasarkan geografi, demografi, dan psikografi; menetapkan target market untuk pengembangan bisnis; dan dapat memposisikan diri di tengah-tengah masyarakat. Ide Kreatif melakukan segmentasi geografi berdasarkan dua wilayah Indonesia bagian timur dan barat. Akan tetapi ekspansi yang mendapat porsi utama yaitu wilayah Indonesia Timur. Hal ini dikarenakan selama ini pelanggan berdomisili di wilayah Indonesia Timur. 
Kemudian untuk segmentasi demografi, Ide Kreatif menetapkan umur, jenis kelamin, siklus kehidupan keluarga, dan kawin atau belum kawin sebagai indikator. Selanjutnya untuk segmentasi psikografi didasarkan pada status sosial di masyarakat, gaya hidup hedonis atau sederhana. dan 4 tipe kepribadian seseorang: sanguinis, melankolis, koleris, dan plegmatis (Febriyantoro, 2016).

Unsur kedua dari STP adalah targetting. Dalam hal ini, proyeksi pasar yang akan menjadi target Ide Kreatif adalah penulis besar dan calon penulis besar untuk penawaran jasa dan seluruh elemen masyarakat mulai anak-anak hingga dewasa untuk penawaran produk. Kedua unsur target pada penawaran jasa tersebut merupakan sesuatu yang potensial dalam pengembangan bisnis Ide Kreatif. Hal ini dikarenakan penulis besar yang sudah memiliki nama akan membantu mempromosikan Ide Kreatif, sementara calon penulis besar akan menjadikan Ide Kreatif sebagai salah satu pihak yang berkepentingan dalam mencapai mimpi yang diinginkannya. Kemudian untuk penawaran produk dari seluruh elemen masyarakat juga potensial, jika pendistribusian produk disesuaikan dengan kalangan masing-masing. Misal buku dongeng untuk anakanak, buku novel untuk remaja, dan buku motivasi untuk dewasa. Selanjutnya untuk unsur STP terakhir yaitu positioning. Ide Kreatif ingin memposisikan diri sebagai penerbit yang merupakan sahabat para penulis dengan pelayanan dan kualitas terbaik yang pernah ada. Dengan demikian, menurut indikator kedua. usaha bisnis Ide Kreatif juga dapat dikatakan layak (Febriyantoro \& Arisandi, 2018)

Indikator ketiga yaitu marketing mix yang terdiri dari 4 unsur. Unsur pertama yaitu product, dimana produk Ide Kreatif akan diproyeksikan sebagai 
produk yang disesuaikan dengan keinginan pelanggan. Mulai dari model buku, ketebalan, warna, jenis kertas, isi naskah, kualitas naskah, dan lainnya. Dengan mengabulkan permintaan produk yang diinginkan pelanggan, maka akan menjadi daya tarik tersendiri. Unsur kedua dari marketing mix yaitu price, harga. Dalam uraian pembahasan di atas telah dijelaskan bahwa harga yang ditetapkan oleh Ide Kreatif relatif lebih murah dengan kompetitor lainnya. Ini menunjukkan bahwa harga Ide Kreatif cukup bersaing. Kemudian unsur ketiga yaitu place, dimana tempat atau lokasi kantor yang dimiliki harus mudah untuk diakses, dijangkau, dan ditemukan. Ide Kreatif yang memiliki kantor di wilayah Rungkut akan dipindahkan ke wilayah Karah yang lebih mudah dijangkau, diakses, dan ditemukan tersebut. Unsur terakhir yaitu promotion. Selama ini Ide Kreatif melakukan promosi melalui 3 cara, antara lain: pemasaran via internet (facebook dan twitter), personal selling, dan publikasi di acara seminar-seminar. Untuk proyeksi ke depan, Ide Kreatif akan mengoptimalkan pemasaran via internet dengan membuat sebuah website resmi Ide Kreatif. Dari website itulah, semua tentang Ide Kreatif dapat dideskripsikan. Dari keempat unsur tersebut, Ide Kreatif mampu mempunyai keunggulan dan menetapkan proyeksi dari masing-masing unsur dalam rangka melakukan rencana pengembangan bisnisnya. Dengan demikian, indikator marketing mix ini juga dapat dikatakan layak.

Dari deskripsi kriteria kelayakan Ide Kreatif aspek pasar dan pemasaran di atas, maka dapat diringkas dalam Tabel 4.6. berikut. 
Tabel 4.6.

Kriteria Kelayakan Aspek Pasar dan Pemasaran Ide Kreatif

\begin{tabular}{|c|c|c|c|}
\hline No & Indikator & Penjelasan & Hasil \\
\hline 1 & SWOT & $\begin{array}{l}\text { Posisi strategi yang dimiliki Ide Kreatif berada pada kuadran } \\
1 \text { yang menunjukkan strategi agresif harus digunakan. }\end{array}$ & Layak \\
\hline 2 & STP & $\begin{array}{l}\text { - Perusahaan dapat menetapkan segmentasi secara geografi } \\
\text { (Indonesia Timur dan Indonesia Barat), demografi (umur, } \\
\text { jenis kelamin, siklus kehidupan keluarga, dan kawin atau } \\
\text { belum kawin), dan psikografi (status sosial di masyarakat, } \\
\text { gaya hidup hedonis atau sederhana, dan } 4 \text { tipe kepribadian } \\
\text { seseorang: sanguinis, melankolis, koleris, plegmatis). } \\
\text { - Perusahaan dapat menentukan target market yang dituju. } \\
\text { Dimana penawaran jasa pada penulis besar dan calon } \\
\text { penulis besar. sementara penawaran produk pada seluruh } \\
\text { elemen masyarakat mulai dari anak-anak hingga dewasa. } \\
\text { - Perusahaan dapat memposisikan diri sebagai sahabat } \\
\text { penulis dalam penawaran jasanya dan kualitas terbaik yang } \\
\text { dirasakan konsumen dalam penawaran produknya. }\end{array}$ & Layak \\
\hline 3 & $\begin{array}{l}\text { Marketing } \\
\text { Mix }\end{array}$ & $\begin{array}{l}\text { - Perusahaan mempunyai produk dengan berbagai macam } \\
\text { model, ketebalan, warna, isi naskah, kualitas naskah, dan } \\
\text { lainnya untuk memenuhi permintaan konsumen. } \\
\text { - Perusahaan menetapkan harga yang dapat bersaing dengan } \\
\text { kompetitor. } \\
\text { - Perusahaan mempunyai tempat usaha yang tepat di } \\
\text { Surabaya. yaitu di wilayah Karah yang akan pindah dari } \\
\text { kantor sekarang di wilayah Rungkut. } \\
\text { - Perusahaan akan membuat sebuah website resmi yang akan } \\
\text { mendeskripsikan penawaran jasa dan produk yang } \\
\text { ditawarkan untuk meningkatkan keuntungan perusahaan. } \\
\text { Dalam hal ini diutamakan pada peningkatan penjualan. }\end{array}$ & Layak \\
\hline
\end{tabular}

Sumber: Data Primer. diolah

Dari Tabel 4.6. di atas dapat dilihat bahwa semua indikator kriteria kelayakan aspek pasar dan pemasaran Ide Kreatif dikatakan layak. Hal ini menunjukkan bahwa usaha bisnis Ide Kreatif dapat layak melakukan rencana pengembangan bisnisnya jika dilihat dari aspek pasar dan pemasaran. Dengan demikian. manajemen harus menangkap berbagai peluang yang ada agar Ide Kreatif mampu mengembangkan bisnisnya dan mampu mempertahankan eksistensi dalam dunia usaha penerbitan di Indonesia. 


\section{Aspek Manajemen}

\section{Kondisi Saat Ini}

Saat ini. usaha bisnis Ide Kreatif dijalankan oleh 4 orang. Adapun dua anggota bekerja di dua divisi, yaitu divisi penerbitan dan divisi distribusi. Sementara dua lainnya bekerja sebagai editor dan pembuat desain. Penulis disini mempunyai tugas rangkap, yaitu merangkap tugas sebagai divisi penerbitan dan menjadi Direktur Utama. Dengan demikian, keseluruhan SDM (Sumber Daya Manusia) yang ada di Ide Kreatif berjumlah 4 orang. Adapun struktur organisasi untuk kondisi saat ini dapat dilihat pada gambar berikut.

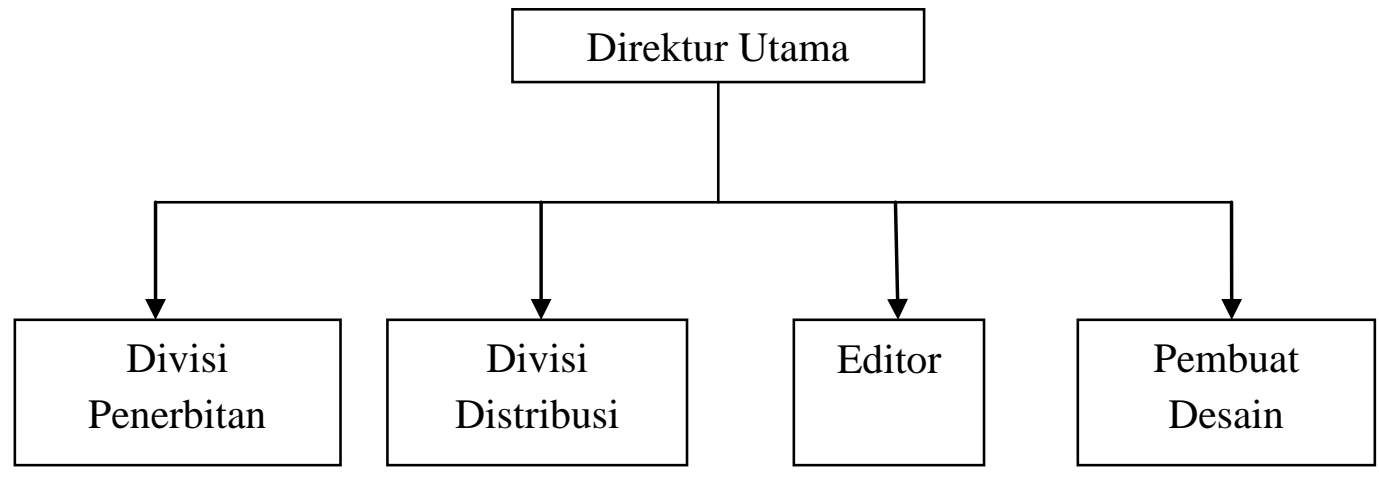

Gambar 4.4.

Struktur Organisasi Ide Kreatif Saat Ini

Sumber: Data Primer. diolah

\section{Pembahasan}

Dalam aspek manajemen ini, akan dibahas tentang 3 indikator, antara lain: jumlah tenaga kerja, kualifikasi tenaga kerja, dan penetapan gaji tenaga kerja. Adapun pembahasan akan dibahas satu persatu. Pembahasan pertama yaitu tentang jumlah tenaga kerja. 
Seperti yang telah disebutkan di atas, bahwa jumlah tenaga kerja saat ini yang ada di Ide Kreatif adalah 4 orang dengan pembagian tanggung jawab pekerjaan sebagai penerbitan yang merangkap Direktur Utama, distribusi, pembuat desain, dan editor. Dengan tanggung jawab pekerjaan yang berat, jumlah tenaga kerja tersebut belumlah cukup. Apalagi proyeksi pengembangan usaha bisnis ini ke depannya untuk menjadi penerbit konvensional, akan membutuhkan tenaga kerja yang lebih banyak.

Tenaga kerja yang berjumlah 4 tersebut bekerja dengan kapasitas Ide Kreatif sebagai sebuah penerbit independen yang hanya mengusahakan editing, desain, dan pendistribusian buku. Sementara percetakan dilimpahkan kepada pihak lain, tapi masih dalam pengawasan SDM Ide Kreatif. Pengembangan bisnis yang akan dilakukan, Ide Kreatif akan melakukan proses editing, desain, percetakan, dan pengepakan. Sementara pendistribusian akan diserahkan pada distributor atau agen. Hal ini menunjukkan bahwa beban pekerjaan Ide Kreatif akan semakin bertambah. Dengan beban pekerjaan yang bertambah tersebut, paling tidak Ide Kreatif harus menambah SDM untuk dipekerjakan. Proyeksi jumlah tenaga kerja akan menjadi 7 orang, termasuk penulis sebagai Direktur Utama.

Adapun ketujuh orang tersebut dibagi menurut tanggung jawab pekerjaan masing-masing antara lain: 4 orang pada divisi produksi ( 2 orang lagi bertugas untuk mencetak buku, 1 orang untuk membuat desain, dan 1 orang editor), 2 orang pada divisi pengiriman (kurir dan penanggung jawab pengiriman), dan 1 orang sebagai Direktur Utama. Penulis disini berperan sebagai Direktur Utama yang bertugas mengkoordinir semua kegiatan bisnis yang dilakukan Ide Kreatif. 
Kemudian sebagai penanggung jawab divisi pengiriman, yaitu Victor Yuwono. rekan bisnis penulis. Dengan bertambahnya jumlah tenaga kerja di Ide Kreatif. diharapkan akan mampu meningkatkan penjualan produk Ide Kreatif.

Kemudian indikator kedua yaitu tentang kualifikasi tenaga kerja. Adapun saat ini 4 tenaga kerja tersebut hanya satu yang memenuhi, yaitu bagian distribusi yang memiliki latar belakang pendidikan pemasaran (marketing). Sementara ketiga lainnya belum ada kesesuaian latar belakang pendidikan, walaupun sebenarnya mereka memiliki kemampuan dalam bidang pekerjaan yang saat ini dikerjakan. Proyeksi ke depan, tentu Ide Kreatif ingin memiliki tenaga kerja yang berkualitas untuk mendukung proyeksi pengembangan bisnis yang akan dilakukan Ide Kreatif.

Manajemen Ide Kreatif telah menentukan kualifikasi tenaga kerja yang akan dipekerjakan. Pertama yaitu divisi produksi yang terdiri dari 3 bagian, antara lain: editor, pembuat desain, dan percetakan. Untuk klasifikasi tenaga kerja editor antara lain:

1. Lulusan SMA;

2. Hobi menulis dan mempunyai beberapa karya (cerita fiksi dan nonfiksi);

3. Berpengalaman sebagai jurnalis minimal selama 1 tahun;

4. Rajin membaca dan teliti;

5. Jujur dan bertanggung jawab.

Adapun kualifikasi tentang hobi menulis dan rajin membaca tersebut adalah mutlak. Hal ini dikarenakan seorang editor harus mampu memperbaiki sebuah naskah sehingga naskah tersebut menjadi lebih baik. Jika seseorang hanya hobi menulis tanpa rajin membaca. hal ini dapat diibaratkan seseorang yang bermimpi 
namun tidak pernah bertindak. Hal ini dikarenakan dengan membaca. maka pengetahuan seseorang tentang naskah yang bagus akan bertambah. sehingga kualitas tulisannya juga akan menjadi lebih baik. Selain itu. seorang editor harus memiliki ketelitian yang bagus. karena akan mengedit per kata dari beberapa naskah yang akan diterbitkan oleh Ide Kreatif.

Kemudian kualifikasi untuk pembuat desain dapat disebutkan sebagai berikut:

1. Lulusan SMK jurusan teknik informatika;

2. Berpengalaman membuat desain selama minimal 1 tahun;

3. Memiliki daya imajinasi yang tinggi;

4. Suka tantangan;

5. Jujur dan bertanggung jawab.

Seorang pembuat desain harus mampu berimajinasi yang kemudian akan diekspresikan pada sebuah desain. Hal ini bukanlah hal yang mudah, karena tidak semua orang memiliki kemampuan tersebut. Oleh karenanya, manajemen Ide Kreatif harus mampu menilai SDM yang memiliki daya imajinasi tinggi, misalnya dengan diberikan tes menggambar, menulis impian yang dimiliki, mendeskripsikan suatu peristiwa, dan lainnya (Febriyantoro, 2018).

Selanjutnya yaitu kualifikasi untuk bagian percetakan antara lain:

1. Lulusan SMA;

2. Berpengalaman dalam usaha percetakan minimal 1 tahun;

3. Teliti;

4. Jujur dan bertanggung jawab. 
Dari beberapa kualifikasi di atas, dapat dijelaskan bahwa sebenarnya semua orang mampu bekerja di bagian percetakan. Tapi karena rencana pengembangan bisnis Ide Kreatif bukan hal yang mudah, maka tenaga kerja yang dipekerjakan haruslah memiliki kualitas lain, yaitu teliti. Hal ini dikarenakan jika seorang pencetak buku tidak teliti. maka akan melakukan pekerjaan dengan sembarangan, sehingga hasilnya akan mengecewakan.

Kemudian kedua yaitu untuk divisi pengiriman. Dalam hal ini, Ide Kreatif membutuhkan seorang kurir y: Direktur Utama hgantar produk ke agen maupun distributor yang ada dengan kualifiklasinya antara lain:
1. Lulusan S Divisi Produksi
Divisi Pengiriman

2. Memiliki pengałaman kerja di bidang pengiriman dan pemasaran minimal 1 3. Menguasai jalan \begin{tabular}{c|c|c|} 
Pembuat \\
Desain
\end{tabular} $\begin{aligned} & \text { Editor } \\
& \text { Kurir } \\
& \text { erah Surabaya dan sekitarnya; }\end{aligned}$

4. Jujur. rajin. bertanggung jawab. dan pantang menyerah;

5. Mempunyai kendaraan.

Dengan memenuhi kelima kriteria tersebut, maka proyeksi pengembangan bisnis Ide Kreatif akan dapat dijalankan. Terlebih lagi untuk ke depannya, sasaran Ide Kreatif adalah dengan menambah jumlah konsumen yang membaca produk Ide Kreatif. Hal ini menuntut manajemen Ide Kreatif harus mampu mendistribusikan produknya ke seluruh wilayah yang berpotensi untuk menjadi konsumen pembaca produk Ide Kreatif.

Dari proyeksi tersebut. dapat dibentuk gambar tentang proyeksi struktur organisasi Ide Kreatif sebagai berikut. 


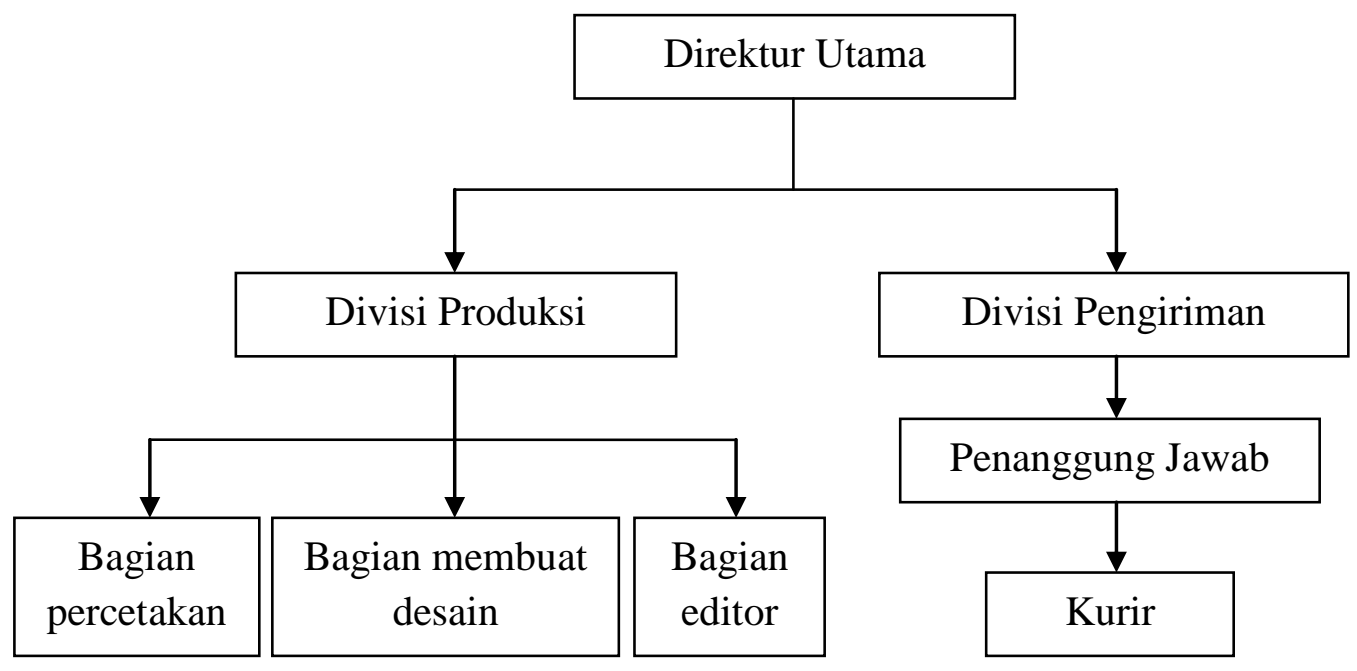

Gambar 4.5.

Proyeksi Struktur Organisasi Ide Kreatif Sumber: Data Primer. Diolah

Selanjutnya untuk indikator ketiga dari aspek manajemen adalah tentang penetapan gaji tenaga kerja. Saat ini, pemberian gaji atau upah kepada tenaga kerja yang dimiliki belumlah memenuhi UMK (Upah Minimum Kota) Surabaya. Hal ini dikarenakan keuntungan yang didapatkan oleh Ide Kreatif juga belum memenuhi kebutuhan yang ada. Untuk proyeksi ke depan dengan rencana pengembangan bisnis yang ada, Ide Kreatif menginginkan penetapan gaji tenaga kerja sesuai UMK Surabaya. Hal ini akan mampu menguntungkan manajemen dan tenaga kerja. Di satu sisi tenaga kerja merasa haknya dipenuhi. di sisi lain manajemen merasa telah memenuhi kewajibannya sebagai pelaku usaha.

\section{Kriteria Kelayakan}


Kriteria kelayakan pada aspek manajemen ini dapat dilihat dari 3 indikatornya. Indikator pertama yaitu tentang jumlah tenaga kerja. Saat ini jumlah tenaga kerja yang ada hanya 4 orang, dengan 1 orang merangkap sebagai penerbitan dan Direktur Utama. Sementara sejalan dengan rencana pengembangan bisnis yang ada. manajemen Ide Kreatif akan menambahnya menjadi 6 orang yang terbagi pada divisi produksi dan pengiriman. Keenam orang tersebut akan dikoordinatori oleh penulis yang akan berperan sebagai Direktur Utama. Dengan bertambahnya jumlah tenaga kerja tersebut, diharapkan akan mendukung rencana pengembangan bisnis yang ada.

Indikator kedua yaitu tentang kualifikasi tenaga kerja. Adapun kualifikasi tenaga kerja ini akan disesuaikan dengan latar belakang pendidikan, sikap, dan karakter tenaga kerja. Pertama yaitu kualifikasi tenaga kerja pembuat desain, antara lain: lulusan SMK jurusan teknik informatika; berpengalaman membuat desain selama minimal 1 tahun; memiliki daya imajinasi yang tinggi; suka tantangan; serta jujur dan bertanggung jawab. Kemudian kualifikasi tenaga kerja percetakan, antara lain: lulusan SMA; berpengalaman dalam usaha percetakan minimal 1 tahun; teliti; serta jujur dan bertanggung jawab. Dengan berbagai kualifikasi tersebut, diharapkan Ide Kreatif akan memiliki SDM yang berkualitas sehingga mampu mendukung rencana pengembangan bisnis yang ada.

Selanjutnya indikator ketiga yaitu penetapan gaji tenaga kerja. Selama ini. tenaga kerja hanya diberikan gaji dengan nominal jauh dari ketetapan UMK Surabaya. Hal ini dikarenakan belum terpenuhinya target penjualan Ide Kreatif. Adapun proyeksi ke depannya. manajemen Ide Kreatif menginginkan penetapan gaji tenaga kerjanya disesuaikan dengan UMK Surabaya. Dengan penetapan gaji 
tenaga kerja sesuai UMK Surabaya. maka manajemen Ide Kreatif akan mampu menjalankan ketetapan pemerintah dan mampu memberikan hak tenaga kerja sesuai porsinya. Dengan demikian. rencana pengembangan bisnis akan dapat berjalan sesuai rencana yang ditetapkan.

Berdasarkan uraian di atas, maka kriteria kelayakan aspek manajemen usaha bisnis Ide Kreatif dapat disimpulkan dengan melihat Tabel 4.7. berikut.

Tabel 4.7.

Kriteria Kelayakan Aspek Manajemen Ide Kreatif

\begin{tabular}{|c|l|l|c|}
\hline No & Indikator & \multicolumn{1}{|c|}{ Penjelasan } & Hasil \\
\hline 1 & $\begin{array}{l}\text { Jumlah } \\
\text { tenaga kerja }\end{array}$ & $\begin{array}{l}\text { Jumlah tenaga kerja saat ini berjumlah 4 orang, dengan } \\
\text { penulis yang merangkap sebagai Direktur Utama dan } \\
\text { penerbitan. Untuk proyeksi, akan memiliki 7 tenaga kerja. }\end{array}$ & Layak \\
\hline 2 & $\begin{array}{l}\text { Kualifikasi } \\
\text { tenaga kerja }\end{array}$ & $\begin{array}{l}\text { Kualifikasi tenaga kerja saat ini belum sesuai dengan latar } \\
\text { belakang pendidikan yang dimiliki. Dengan demikian, } \\
\text { manajemen Ide Kreatif menentukan kualifikasi tenaga } \\
\text { kerja sebagai proyeksi mendukung rencana pengembangan } \\
\text { bisnis disesuaikan dengan latar belakang pendidikan. sikap. } \\
\text { dan perilaku yang dimiliki. }\end{array}$ & Layak \\
\hline 3 & $\begin{array}{l}\text { Penetapan } \\
\text { gaji tenaga } \\
\text { kerja }\end{array}$ & $\begin{array}{l}\text { Penetapan gaji saat ini belum sesuai UMK Surabaya karena } \\
\text { hasil penjualan belum memenuhi omset yang ditetapkan. } \\
\text { Ke depannya. penetapan gaji tenaga kerja akan disesuaikan } \\
\text { dengan UMK Surabaya untuk menjalankan peraturan } \\
\text { pemerintah dan memenuhi hak tenaga kerja. }\end{array}$ & Layak \\
\hline
\end{tabular}

Sumber: Data Primer. diolah

Dari Tabel 4.7. di atas dapat dilihat bahwa ketiga indikator dalam aspek manajemen memenuhi kriteria kelayakan yang telah ditentukan. Dengan demikian, rencana pengembangan bisnis yang telah ditetapkan Ide Kreatif dapat dijalankan.

\section{Aspek Teknis dan Teknologi}

\section{Kondisi Saat Ini}

Lokasi bisnis saat ini berada di Rungkut Kidul I nomor 11 Surabaya. Adapun peralatan yang ada di kantor tersebut hanya ada 2 unit komputer yang 
digunakan untuk editor dan pembuat desain. Hal ini dikarenakan saat ini Ide Kreatif hanya melayani editing dan pembuatan desain, sementara percetakan diberikan kepada percetakan lain karena Ide Kreatif belum memiliki mesin-mesin yang digunakan untuk mencetak sebuah buku. Dalam kantor tersebut, hanya berupa dua ruangan yang cukup sempit. Satu ruangan digunakan untuk bekerja dan ruangan yang lain digunakan untuk menerima tamu.

\section{Pembahasan}

Pembahasan dari aspek teknis dan teknologi ini akan meliputi 3 indikator, antara lain: lokasi bisnis, peralatan, dan layout. Pembahasan pertama ada pada lokasi bisnis. Saat ini, lokasi bisnis Ide Kreatif ada di wilayah Rungkut dengan alamat lengkap di Rungkut Kidul I nomor 11 Surabaya. Menurut analisis hemat penulis selama ini, lokasi bisnis tersebut belum memiliki nilai jual yang cukup tinggi. Hal ini dikarenakan kesulitan akses dan jangkauan bagi calon konsumen, calon distributor, dan calon penulis yang akan diterbitkan karyanya oleh Ide Kreatif. Hal ini dikarenakan wilayah Rungkut terkenal dengan kemacetannya dengan wilayah industri yang cukup banyak. Selain macet, wilayah tersebut juga berada di pinggiran kota Surabaya, sehingga akses ke kantor relatif cukup sulit. Melihat hal tersebut, maka lokasi bisnis harus dipindahkan ke wilayah yang lebih baik untuk mengimplementasikan rencana pengembangan bisnis yang telah ditetapkan.

Penulis telah mendapatkan tempat lain yang akan digunakan sebagai kantor di daerah Karah, dengan alamat lengkap di Jalan Karah Agung Nomor 43- 
G Surabaya. Adapun beberapa hal yang mendasari pemilihan lokasi bisnis tersebut antara lain:

1. Akses jalan kelar masuk sangat mudah, karena jalannya lebar dan berada di tepi jalan raya;

2. Wilayahnya aman dari banjir;

3. Posisi lumayan strategis walaupun berada di pinggiran kota, karena tidak terkenal daerah macet atau lainnya.

Dengan beberapa alasan tersebut, dipilihlah Karah sebagai kantor yang akan menjadi tempat Ide Kreatif untuk melakukan rencana pengembangan usaha. Adapun gambar dari kantor tersebut telah dijelaskan di atas, yaitu pada Gambar 4.3. Selain itu, biaya sewa yang ditawarkan pun merupakan salah satu faktor yang menyebabkan tempat tersebut dapat menjadi proyeksi kantor selanjutnya. Adapun biaya sewa yag ditawarkan sebesar Rp 25.000.000.00 per tahun.

Indikator kedua yaitu peralatan. Kondisi saat ini di wilayah Rungkut, Ide Kreatif hanya memiliki 2 unit komputer. Hal ini didasarkan pada jumlah tenaga kerja dan keperluan. Namun untuk melakukan pengembangan bisnisnya, Ide Kreatif memerlukan beberapa peralatan tambahan. Adapun penambahan peralatan tersebut dapat dilihat pada Tabel 4.8. berikut, 
Tabel 4.8.

Proyeksi Penambahan Peralatan di Kantor Baru Ide Kreatif

\begin{tabular}{|c|c|c|c|}
\hline No & Nama Alat dan Gambar & Jumlah & Spesifikasi \\
\hline 1. & & 1 & $\begin{array}{l}\text { Penggunaan: Semi otomatis } \\
\text { Kapasitas Jilid: } 180 \text { buku per jam } \\
\text { Ketebalan Maksimal: } 5 \mathrm{~cm} \\
\text { Ukuran Jilid Minimal: Postcard } \\
\text { Ukuran Jilid Maksimal: A3+ }(310 \times 430 \mathrm{~mm}) \\
\text { Proses: Hard Cover dan Soft Cover } \\
\text { Power Supply: } 220 \mathrm{~V} / 300 \text { Watt } \\
\text { Garansi Produk: } 1 \text { tahun } \\
\text { Harga: Rp } 8.700 .000 .00\end{array}$ \\
\hline 2. & Mesin Ceta & 1 & $\begin{array}{l}\text { Area Cetak Maksimal: } 25 \times 34 \mathrm{~cm} \\
\text { Area Kertas Maksimal: } 29,5 \times 37,9 \mathrm{~cm} \\
\text { Area Kertas Minimal: } 7,5 \times 9,5 \mathrm{~cm} \\
\text { Buatan: Jepang } \\
\text { Mesin percetakan paling kuat, bandel, dan } \\
\text { handal performanya } \\
\text { Ukuran kecil dan mudah perawatan } \\
\text { Spare part mesin banyak tersedia di pasaran } \\
\text { Harga: Rp } 34.000 .000 .00\end{array}$ \\
\hline 3. & & 1 & $\begin{array}{l}\text { Merek dan Tipe: Hayashi HST } 4020 \\
\text { Daya Listrik: } 12000 \text { Watt } \\
\text { Daya Voltase: } 380 \mathrm{~V}, 50 \mathrm{~Hz}, 3 \text { Phase } \\
\text { Temperatur Tunnel: } 190^{\circ} \mathrm{C} \\
\text { Kecepatan Conveyor: } 0-15 \text { meter/menit } \\
\text { Tinggi Conveyor: } 700 \mathrm{~mm} \\
\text { Dimensi Tunnel: }(400 \times 900 \times 200) \mathrm{mm} \\
\text { Dimensi Mesin: }(620 \times 1500 \times 1070) \mathrm{mm} \\
\text { Harga: Rp } 24.500 .000 .00\end{array}$ \\
\hline 4. & $\begin{array}{c}\text { Mesin Potong Kertas } 1 \\
\text { Rim Tipe } 868\end{array}$ & 1 & $\begin{array}{l}\text { Mesin potong kertas heavy duty } \\
\text { Memotong kertas dengan ketebalan } 1 \text { rim } \\
\text { Pisau tajam } \\
\text { Konstruksi dibuat dari logam pilihan yang } \\
\text { daya tahan mesin lama } \\
\text { Mudah mengganti mata pisau } \\
\text { Ukuran maksimum potong: kertas ukuran } \\
\text { dobel folio } \\
\text { Penggerak: roda pemutar } \\
\text { Berat: } 32 \mathrm{~kg} \\
\text { Harga: } \operatorname{Rp} 2.800 .000 .00\end{array}$ \\
\hline
\end{tabular}

Sumber: Data Primer, diolah 
Dari Tabel 4.8. di atas dapat diketahui bahwa untuk ke depannya, Ide Kreatif akan menambah 4 peralatan tersebut agar rencana pengembangan bisnis dapat dilakukan dengan maksimal.

Indikator ketiga yaitu layout kantor. Kantor saat ini yang berada di Rungkut, hanya memiliki 2 ruangan yang digunakan untuk bekerja dan menerima tamu. Adapun gambarnya dapat dilihat pada Gambar 4.4. berikut,

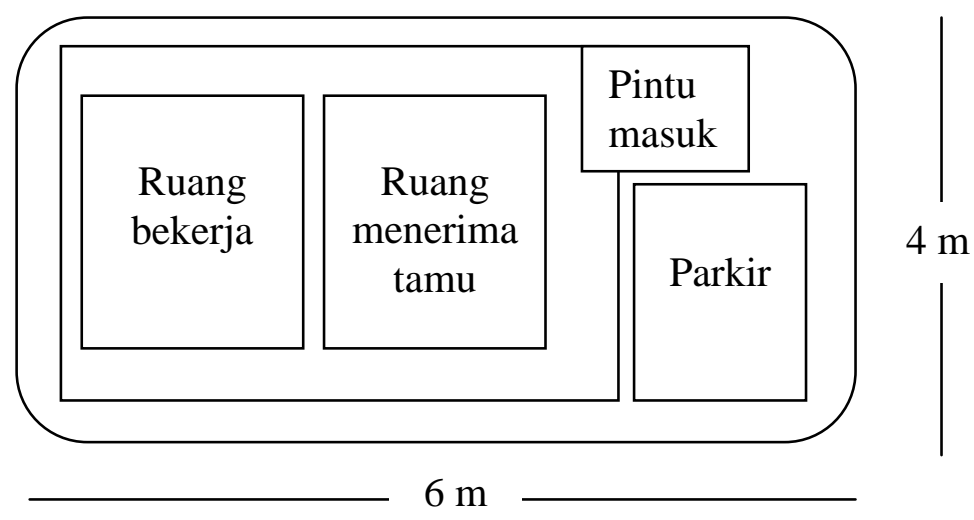

Gambar 4.4.

Layout Kantor di Rungkut

Sumber: Data Primer, diolah

Dari Gambar 4.4. tersebut dapat dilihat bahwa ruangan yang ada begitu sempit dan penuh sesak karena hanya berukuran $8 \times 4 \mathrm{~m}$ saja. Empat orang yang bekerja menjadi satu ruangan dengan berbagai kesibukan, hal ini kemungkinan besar dapat mengganggu konsentrasi masing-masing orang, terutama editor dan pembuat desain.

Dengan rencana pengembangan bisnis yang telah disusun, maka Ide Kreatif harus memindahkan lokasi bisnisnya ke tempat yang lebih luas dan lebih mudah aksesnya. Oleh karenanya, dipilihlah daerah Karah sebagai lokasi bisnis yang akan dituju. Adapun alamat lengkap dan alasannya seperti telah dijelaskan pada indikator pertama aspek teknis dan teknologi ini. Selain ketiga faktor 
tersebut, ada alasan yang lebih menguntungkan yaitu dengan luas kantor yang lebih besar dibandingkan di Rungkut. Adapun proyeksi layout kantor di Karah dapat dilihat pada Gambar 4.5. berikut,

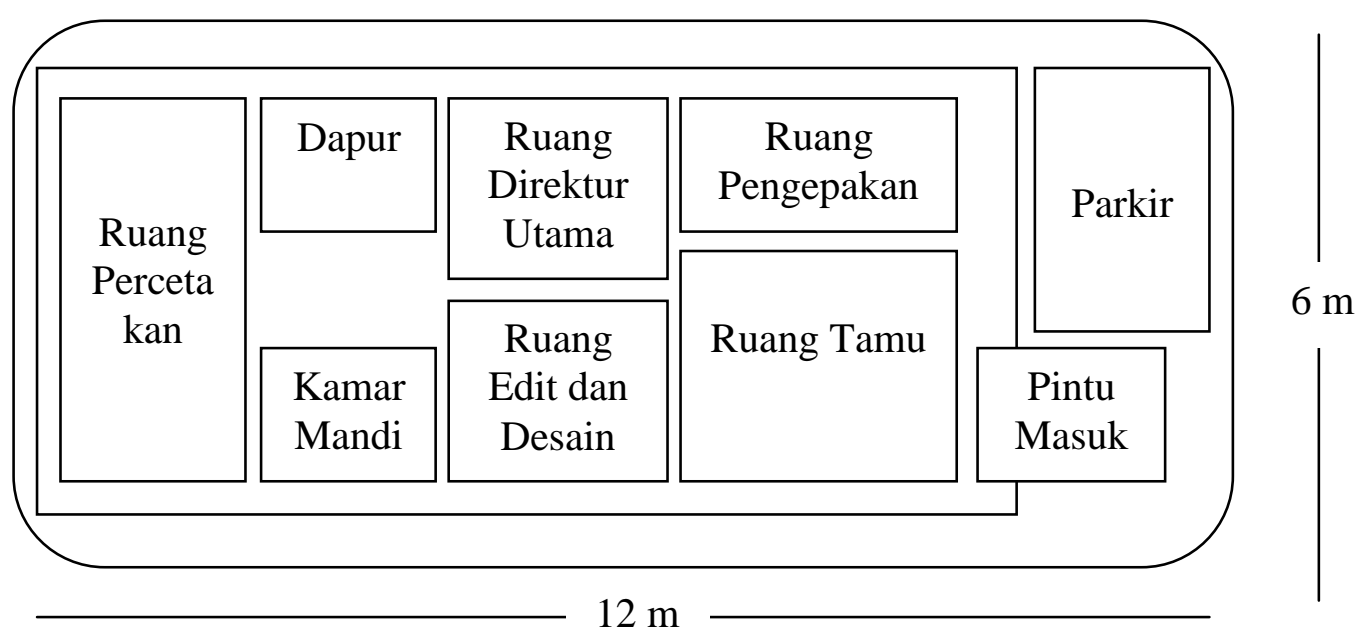

Gambar 4.5.

Proyeksi Layout Kantor Ide Kreatif di Karah

Sumber: Data Primer, diolah

Adapun semua peralatan percetakan diletakkan di ruang percetakan yang memiliki luas lebih besar dibandingkan ruangan lainnya. Dari Gambar 4.5. di atas dapat dilihat bahwa dengan luas kantor yang bertambah besar, maka masing-masing tenaga kerja akan memiliki tempat tersendiri yang luas dan nyaman. Dengan demikian, konsentrasi untuk bekerja akan dapat bertambah. Hal ini akan berdampak baik untuk peningkatan volume produksi dan penjualan Ide Kreatif sesuai dengan rencana pengembangan bisnis yang telah ditentukan. Hal ini dikarenakan kenyamanan akan memberikan motivasi bagi seseorang untuk melakukan pekerjaan dengan lebih baik. Dengan luas tiga kali lebih besar dari luas kantor sebelumnya, diharapkan keuntungan juga meningkat sama.

\section{Kriteria Kelayakan}


Kriteria kelayakan aspek teknis dan teknologi dapat dilihat dari 3 indikator, antara lain: letak lokasi bisnis, peralatan, dan layout kantor. Pertama yaitu letak lokasi bisnis, saat ini letak lokasi bisnis di Rungkut belum mampu memiliki nilai jual karena kondisi daerah yang macet dan berada di pinggiran kota sehingga aksesnya relatif sulit. Oleh karenanya, proyeksi ke depan, lokasi bisnis akan dipindahkan ke Karah dengan beberapa alasan, antara lain: akses mudah karena jalan besar, bebas banjir, dan posisi strategis.

Indikator kedua yaitu peralatan. Saat ini, Ide Kreatif hanya memiliki peralatan 2 unit komputer. Padahal proyeksi ke depan, percetakan akan dilakukan oleh Ide Kreatif sendiri. Dengan demikian, diperlukan penambahan peralatan percetakan, antara lain: mesin jilid buku, mesin cetak toko 820, mesin shrink, dan mesin potong kertas 1 rim tipe 868. Dengan penambahan keempat alat tersebut, maka Ide Kreatif akan mampu mencetak bukunya sendiri, sehingga mampu meningkatkan volume produksi. Dengan meningkatnya volume produksi, maka ada kemungkinan untuk meningkatkan pula volume penjualan. Hal ini akan menunjukkan bahwa rencana pengembangan bisnis akan mampu dilakukan dengan baik oleh Ide Kreatif.

Selanjutnya indikator ketiga yaitu layout kantor. Saat ini, luas kantor di Rungkut hanya $24 \mathrm{~m}^{2}$. Oleh karenanya, ruangan hanya dapat dibagi menjadi dua, yaitu ruangan tempat bekerja semua tenaga kerja dan ruangan untuk menerima tamu. Hal ini tentu bukanlah kondisi yang baik dan mampu mendukung kinerja tenaga kerja menjadi lebih baik. Dengan demikian, manajemen berencana memindahkan kantor ke daerah Karah dengan luas kantor mencapai $72 \mathrm{~m}^{2}$ atau tiga kali lipat dari kantor yang ada di Rungkut. Dengan semakin luasnya kantor 
Ide Kreatif, maka pembagian ruangan untuk masing-masing tenaga kerja pada bagian-bagian tertentu akan menjadi lebih maksimal. Hal ini akan mampu meningkatkan kenyamanan dan motivasi tenaga kerja untuk memperbaiki kinerja yang lalu. Dengan demikian, keuntungan perusahaan akan meningkat seiring dengan meningkatnya volume produksi dan volume penjualan produk Ide Kreatif.

Dari ketiga indikator tersebut, kriteria kelayakan aspek teknis dan teknologi dapat dirangkum dan dilihat pada Tabel 4.9. berikut,

Tabel 4.9.

Kriteria Kelayakan Aspek Teknis dan Teknologi Ide Kreatif

\begin{tabular}{|l|l|l|c|}
\hline No & Indikator & \multicolumn{1}{|c|}{ Penjelasan } & Hasil \\
\hline 1 & Lokasi Bisnis & $\begin{array}{l}\text { Di Rungkut tidak memiliki nilai jual dan } \\
\text { letaknya tidak strategis, sehingga pindah ke } \\
\text { Karah. Alasannya karena akses mudah } \\
\text { melewati jalan besar, bebas banjir, dan } \\
\text { posisi strategis. }\end{array}$ & Layak \\
\hline 2 & Peralatan & $\begin{array}{l}\text { Saat ini hanya memiliki 2 unit komputer. } \\
\text { Dikarenakan selanjutnya percetakan akan } \\
\text { dilakukan sendiri, maka akan ada } \\
\text { penambahan mesin jilid buku, mesin cetak } \\
\text { toko 820, mesin shrink, dan mesin potong } \\
\text { kertas 1 rim tipe 868. }\end{array}$ & Layak \\
\hline 3 & Layout & $\begin{array}{l}\text { Saat ini hanya terpisah menjadi dua } \\
\text { ruangan, yang dinilai tidak efisien. Di } \\
\text { kantor yang baru, semua akan memiliki } \\
\text { tempat sendiri-sendiri sesuai beban } \\
\text { pekerjaannya. Diharapkan mampu } \\
\text { meningkatkan kenyamanan dan motivasi } \\
\text { untuk memperbaiki kinerja. }\end{array}$ & Layak \\
\hline
\end{tabular}

Sumber: Data Primer, diolah

Dari Tabel 4.9. di atas dapat dilihat bahwa dari ketiga indikator aspek teknis dan teknologi, hasil yang didapatkan adalah layak. Hal ini menunjukkan bahwa rencana pengembangan bisnis yang dilakukan oleh Ide Kreatif dapat dilakukan.

\section{Aspek Hukum}

\section{Kondisi Saat Ini}


Saat ini, Ide Kreatif belum memiliki bentuk badan usaha. Hal ini dikarenakan belum siapnya Ide Kreatif menjadi bentuk badan usaha. Adapun ketidaksiapan tersebut dikarenakan jumlah tenaga kerja yang masih minim, belum memiliki peralatan percetakan, belum memiliki kantor yang strategis, dan masih ada tenaga kerja yang merangkap jabatan.

Dengan tidak memiliki bentuk badan usaha tersebut, maka Ide Kreatif tidak dapat membuat ISBN (International Standard Book Number) dan tidak dapat menjadi anggota IKAPI (Ikatan Penerbit Indonesia). Selama ini, Ide Kreatif mendapatkan ISBN dengan cara menggunakan perusahaan lain untuk mendapatkan ISBN. Hal ini dinilai merugikan Ide Kreatif karena harus membayar fee untuk meminjam nama perusahaan lain tersebut.

\section{Pembahasan}

Pembahasan aspek hukum ini sesuai dengan indikator yang telah ditentukan, antara lain: badan usaha perseroan komanditer (CV), syarat penerbit, dan pendaftaran ISBN di Perpustakaan anasional. Pembahasan yang pertama yaitu bentuk badan usaha. Dalam rangka memenuhi kebutuhan untuk menjadi usaha yang lebih besar dengan menjadi anggota IKAPI, maka Ide Kreatif berusaha mendapatkan izin menjadi Perserikatan Komanditer (CV). Untuk memenuhi syarat menjadi CV maka telah diurus berbagai hal berikut:

1. Akta pendirian $\mathrm{CV}$

Pengurusan akta pendirian CV Ide Kreatif telah dilakukan melalui notaris Ermawati, SH yang berkantor di Jalan Gayungsari I No.43 Surabaya. Syarat-syarat yang diperlukan dalam mengajukan Akta Pendirian CV adalah 
fotokopi KTP, kartu keluarga, dan NPWP atas nama Mohammad Trio Febriyantoro dan Victor Yuwono. Mohammad Trio Febriyantoro menjabat direktur utama, sebagai persero pasif. Biaya yang telah dibayarkan untuk mengurus akta pendirian CV tersebut adalah Rp. 1.500.000.00.

2. Pengesahan Pengadilan Negeri

Saat ini Ide Kreatif sedang menunggu Pengesahan Pengadilan Negeri untuk akta pendirian CV, karena dengan adanya Pengesahan Pengadilan Negeri maka persyaratan lain akan dapat dipenuhi. Estimasi biaya pengesahan Pengadilan Negeri ini diperkirakan Rp 1.000.000.00.

3. Surat Keterangan Domisili

Surat Keterangan Domisili CV dapat diperoleh di kantor kelurahan setempat dengan melampirkan fotokopi akta pendirian $\mathrm{CV}$ yang telah disahkan oleh Pengadilan Negeri, perjanjian pinjam pakai atau sewa menyewa atau jual beli tempat usaha dan PBB tahun terakhir dari tempat usaha. Namun karena akta pendirian CV Ide Kreatif belum memperoleh pengesahan dari Pengadilan Negeri, maka proses ini belum dapat dilakukan. Adapun estimasi biaya untuk pengurusan Surat Keterangan Domisili ini adalah Rp 100.000.00.

4. NPWP Perusahaan (Nomor Pokok Wajib Pajak)

NPWP Perusahaan dapat diperoleh dengan melengkapi berbagai syarat, di antaranya adalah Surat Keterangan Domisili. Karena Surat Keterangan Domisili belum dapat diupayakan pembuatannya, maka NPWP juga belum dapat diproses. Estimasi biaya pengurusan NPWP Perusahaan tidak dipungut biaya (gratis). 


\section{SIUP (Surat Ijin Usaha Perdagangan)}

Syarat pengajuan SIUP antara lain adalah dengan menyerahkan fotokopi akta pendirian CV dan NPWP perusahaan, namun karena kedua hal tersebut belum dapat dipenuhi maka proses ini belum dapat dilakukan. Adapun estimasi biaya pengurusan SIUP berkisar Rp 500.000.00.

\section{TDP (Tanda Daftar Perusahaan)}

TDP dapat diperoleh setelah kelima syarat di atas dapat dipenuhi, maka karena empat diantaranya masih belum diperoleh, maka TDP pun belum dapat diproses. Adapun estimasi biaya pengurusan TDP adalah Rp 300.000 .00

Dari keenam unsur dari indikator untuk pengurusan bentuk usaha Ide Kreatif menjadi Perserikatan Komanditer (CV), baru satu syarat yang sudah dilengkapi, namun diyakini bahwa untuk pengurusan akan mudah dilakukan jika sudah diperoleh pengesahan dari Pengadilan Negeri. Maka dapat dikatakan proses menuju bentuk CV sedang dilakukan oleh Ide kreatif, maka usaha ini dapat dikatakan telah layak.

Indikator kedua yaitu syarat menjadi penerbit. Adapun syarat penerbit ini antara lain: akta notaris pendirian CV, NPWP badan usaha, pendaftaran Pengadilan Negeri, SIUP, dan TDP. Semua indikator tersebut telah dijelaskan pada bagian indikator pertama, dimana Ide Kreatif akan menjadi bentuk usaha CV. Dengan demikian, jika Ide Kreatif telah menjadi CV, maka secara langsung Ide Kreatif telah diakui sebagai salah satu penerbit yang ada di Indonesia. 
Selanjutnya akan mengubah bentuk Ide Kreatif dari perusahaan independen menjadi perusahaan konvensional, seperti Gramedia Pustaka, Mizan, Mic Publishing, dan lainnya. Dengan menjadi penerbit konvensional, maka Ide Kreatif akan membeli naskah penulis dan penulis akan mendapatkan keuntungan dari royalti penjualan bukunya. Hal ini berbeda dengan sebelumnya, dimana penulis mengeluarkan uang untuk biaya percetakan. Dengan demikian, hal ini mampu menarik minat penulis lebih besar dan produk Ide Kreatif juga akan bertambah.

Kemudian untuk indikator ketiga, yaitu tentang pendaftaran ISBN di Perpustakaan Nasional. Adapun persyaratan tersebut antara lain: mengisi formulir surat pernyataan, menunjukkan bukti legalitas penerbit, membuat surat permohonan atas nama penerbit dengan stempel perusahaan untuk buku yang akan diterbitkan, serta mengirimkan lampiran, halaman judul, balik halaman judul, daftar isi, dan kata pengantar. Dengan beberapa syarat tersebut, Ide Kreatif akan mampu memenuhi semua persyaratan jika Ide Kreatif telah berbentuk CV. Dengan demikian, ketiga indikator dalam aspek ini berkaitan antara satu dengan yang lainnya. Jika indikator pertama telah dapat dipenuhi, maka otomatis indikator kedua dan ketiga juga akan dapat dipenuhi oleh Ide Kreatif.

\section{Kriteria Kelayakan}

Kriteria kelayakan aspek hukum Ide Kreatif ini dapat dilihat dari 3 indikator, antara lain: bentuk badan usaha, syarat penerbit, dan syarat pendaftaran ISBN di Perpustakaan Nasional. Proyeksi ke depan, Ide Kreatif akan memiliki bentuk badan usaha berupa $\mathrm{CV}$ yang didaftarkan dengan pemilik dua orang. Adapun persyaratan pendirian $\mathrm{CV}$ antara lain: akta pendirian $\mathrm{CV}$, pengesahan 
Pengadilan Negeri, surat keterangan domisili, NPWP perusahaan, SIUP, dan TDP. Namun, baru satu syarat yang sudah dilengkapi. Akan tetapi diyakini bahwa untuk pengurusan akan mudah dilakukan jika sudah diperoleh pengesahan dari Pengadilan Negeri.

Selanjutnya yaitu tentang syarat penerbit seperti akta notaris pendirian CV, NPWP badan usaha, pendaftaran Pengadilan Negeri, SIUP, dan TDP. Semua akan dapat didapatkan karena otomatis jika Ide Kreatif berbentuk CV, maka Ide Kreatif juga akan diakui sebagai salah satu penerbit di Indonesia. Kemudian untuk indikator ketiga yaitu syarat mendapatkan ISBN di Perpustakaan Nasional, juga cukup mudah jika telah ada form legalitas bentuk badan usaha. Adapun persyaratan tersebut antara lain: mengisi formulir surat pernyataan, menunjukkan bukti legalitas penerbit, membuat surat permohonan atas nama penerbit dengan stempel perusahaan untuk buku yang akan diterbitkan, serta mengirimkan lampiran, halaman judul, balik halaman judul, daftar isi, dan kata pengantar. Dengan demikian, rencana pengembangan bisnis Ide Kreatif ini dapat dilanjutkan. Adapun kriteria kelayakan aspek hukum ini dapat disimpulkan pada Tabel 4.10. berikut, 
Tabel 4.10.

Kriteria Kelayakan Aspek Hukum Ide Kreatif

\begin{tabular}{|l|l|l|c|}
\hline No & \multicolumn{1}{|c|}{ Indikator } & \multicolumn{1}{c|}{ Penjelasan } & Hasil \\
\hline 1. & $\begin{array}{l}\text { Badan Usaha } \\
\text { Perseroan } \\
\text { Komanditer } \\
(\mathrm{CV})\end{array}$ & $\begin{array}{l}\text { Adapun persyaratan pendirian CV antara lain: akta } \\
\text { pendirian CV, pengesahan Pengadilan Negeri, surat } \\
\text { keterangan domisili, NPWP perusahaan, SIUP, dan } \\
\text { TDP. Namun, baru satu syarat yang sudah dilengkapi. } \\
\text { Akan tetapi diyakini bahwa untuk pengurusan akan } \\
\text { mudah dilakukan jika sudah diperoleh pengesahan } \\
\text { dari Pengadilan Negeri. }\end{array}$ & Layak \\
\hline 2. & Syarat Penerbit & $\begin{array}{l}\text { Syarat penerbit seperti akta notaris pendirian CV, } \\
\text { NPWP badan usaha, pendaftaran Pengadilan Negeri, } \\
\text { SIUP, dan TDP. Semua akan dapat didapatkan karena } \\
\text { otomatis jika Ide Kreatif berbentuk CV. }\end{array}$ & Layak \\
\hline 3. & $\begin{array}{l}\text { Pendaftaran } \\
\text { ISBN } \\
\text { Perpustakaan } \\
\text { Nasional }\end{array}$ & $\begin{array}{l}\text { Persyaratan: mengisi formulir surat pernyataan, } \\
\text { menunjukkan bukti legalitas penerbit, membuat surat } \\
\text { permohonan atas nama penerbit dengan stempel } \\
\text { perusahaan untuk buku yang akan diterbitkan, serta } \\
\text { mengirimkan lampiran, halaman judul, balik halaman } \\
\text { judul, daftar isi, dan kata pengantar. Hal ini akan } \\
\text { mudah jika Ide Kreatif sudah berbentuk CV. }\end{array}$ & Layak \\
\hline
\end{tabular}

Sumber: Data Primer, diolah

Dengan melihat Tabel 4.10. di atas, maka semua hasil dari masing-masing indikator dapat dikatakan layak. Dengan demikian, rencana pengembangan bisnis Ide Kreatif dapat dijalankan oleh manajemen Ide Kreatif.

\section{Aspek Keuangan}

\section{Kondisi Saat Ini}

Sejak pertama kali berdiri pada tanggal 7 Januari 2012. kinerja keuangan Ide Kreatif tidak stabil. Adapun ketidakstabilan tersebut dapat dilihat dari penjualan yang dilakukan Ide Kreatif pada bulan Agustus 2012 hingga bulan Maret 2013 seperti pada Tabel 4.11. berikut. 
Tabel 4.11.

Penjualan Ide Kreatif Bulan Agustus 2012 - Maret 2013

\begin{tabular}{|c|l|cr|}
\hline No & \multicolumn{1}{|c|}{ Bulan dan Tahun } & \multicolumn{2}{c|}{ Total Penjualan } \\
\hline 1 & Agustus 2012 & $\mathrm{Rp}$ & 965.000 \\
\hline 2 & September 2012 & $\mathrm{Rp}$ & 1.920 .000 \\
\hline 3 & Oktober 2012 & $\mathrm{Rp}$ & 868.000 \\
\hline 4 & November 2012 & $\mathrm{Rp}$ & 1.065 .000 \\
\hline 5 & Desember 2012 & $\mathrm{Rp}$ & 1.397 .500 \\
\hline 6 & Januari 2013 & $\mathrm{Rp}$ & 633.750 \\
\hline 7 & Februari 2013 & $\mathrm{Rp}$ & 734.500 \\
\hline 8 & Maret 2013 & $\mathrm{Rp}$ & 942.500 \\
\hline & Total Penjualan & $\mathrm{Rp}$ & 8.526 .250 \\
\hline
\end{tabular}

Sumber: Data Primer. diolah

Dari Tabel 4.11. di atas dapat digambar sebuah grafik batang untuk mempermudah melihat pada bulan apa penjualan tertinggi dan juga sebaliknya. Adapun grafik tersebut dapat dilihat pada Gambar 4.6. berikut.

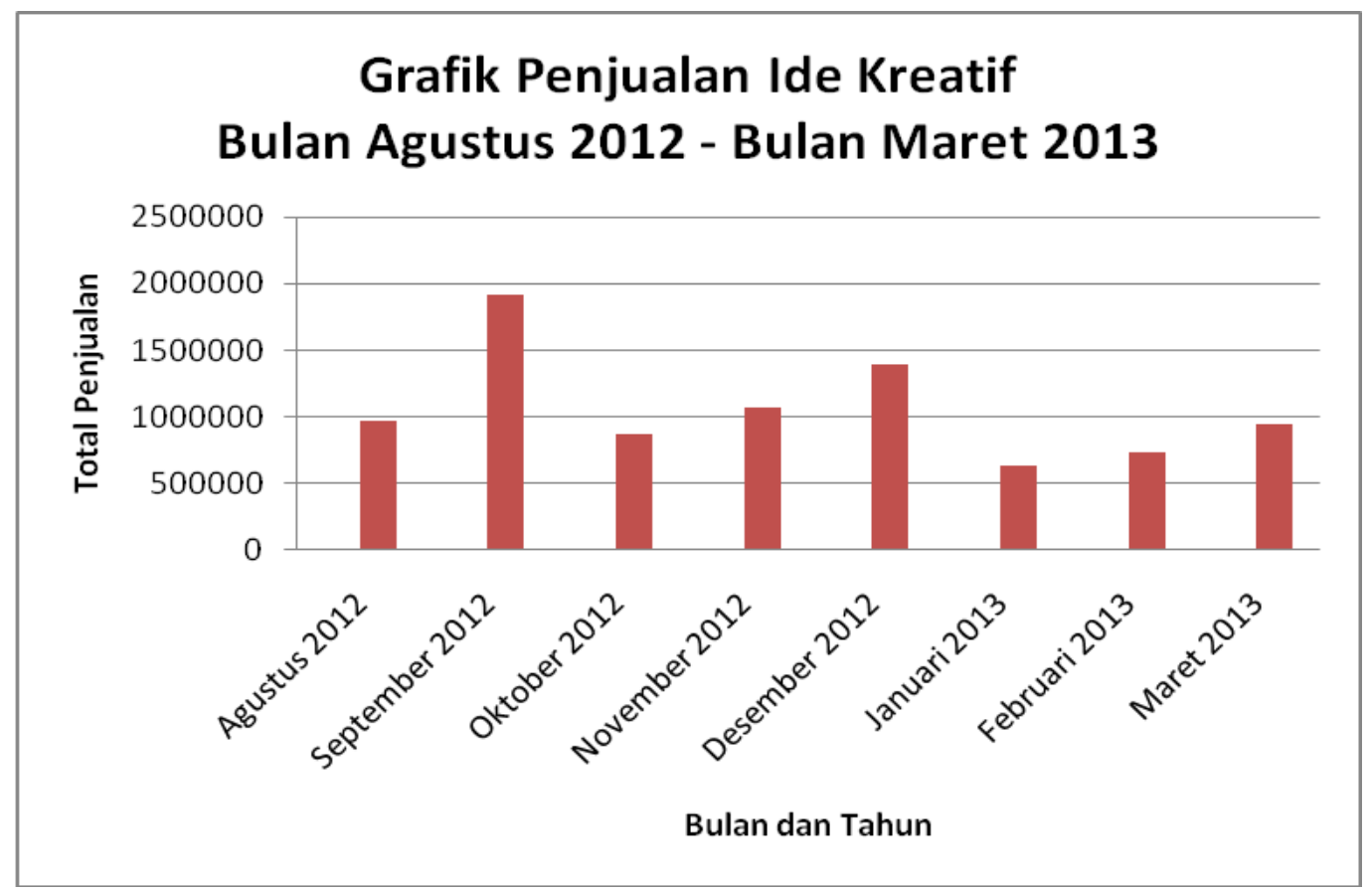

Gambar 4.6.

Grafik Penjualan Ide Kreatif Bulan Agustus 2012 - Bulan Maret 2013

Sumber: Data Primer. diolah 
Dari Gambar 4.6. tersebut dapat dilihat bahwa penjualan tertinggi terjadi pada bulan September 2012. Hal ini dikarenakan pada bulan tersebut. merupakan puncak penjualan buku yang berjudul "Awas Janda". Puncak penjualan buku tersebut dengan dibelinya buku dalam jumlah besar oleh salah satu relasi Ide Kreatif untuk dijual di luar pula. Sementara penjualan terkecil yaitu pada bulan Januari 2013. Adapun alasannya karena saat itu merupakan saat liburan. sehingga masyarakat sibuk dengan urusannya masing-masing dan mengakibatkan penjualan menurun.

\section{Pembahasan}

Pembahasan dalam aspek keuangan ini bertujuan untuk mengetahui berapa jumlah kebutuhan investasi awal. proyeksi laporan keuangan. dan investasi secara finansial. Adapun kesemua hal tersebut saling berhubungan satu dengan yang lain. Penjelasannya sebagai berikut:

\section{Project Cost}

Project Cost merupakan total investasi awal yang dibutuhkan ditambah dengan modal kerja yang tersedia. Adapun investasi awal yang dimaksudkan disini adalah biaya-biaya yang diperlukan di awal usaha Ide Kreatif untuk melakukan rencana pengembangan bisnis yang telah ditentukan. Adapun biaya tersebut meliputi biaya peralatan. biaya pengurusan izin usaha. dan biaya untuk membayar sewa kantor. Sementara modal kerja terdiri dari kas. persediaan. dan perlengkapan yang telah dimiliki. Berikut perhitungan perincian project cost yang dibutuhkan Ide Kreatif dalam melakukan rencana pengembangan usahanya. 
Tabel 4.12.

Proyeksi Penambahan Alat Ide Kreatif

\begin{tabular}{|c|l|c|}
\hline No & \multicolumn{1}{|c|}{ Nama Alat } & Harga \\
\hline 1 & Mesin Jilid Buku & $\operatorname{Rp~} 8.700 .000$ \\
\hline 2 & Mesin Cetak Toko 820 & $\mathrm{Rp} 34.000 .000$ \\
\hline 3 & Mesin Shrink Tunnel & $\mathrm{Rp} \mathrm{24.500.000}$ \\
\hline 4 & Mesin Potong Kertas 1 Rim Tipe 868 & $\mathrm{Rp} \mathrm{2.800.000}$ \\
\hline & \multicolumn{1}{|c|}{ Total Penambahan Alat } & $\mathrm{Rp} \mathrm{70.000.000}$ \\
\hline
\end{tabular}

Sumber: Data Primer. diolah

Tabel 4.12. merupakan keterangan dari proyeksi penambahan alat Ide Kreatif. mengingat dalam rencana pengembangan bisnis yang akan dilakukan. Ide Kreatif akan melakukan percetakan sendiri. Dengan demikian. diperlukan beberapa alat untuk percetakan tersebut.

Tabel 4.13.

Proyeksi Pengurusan Izin Usaha Ide Kreatif

\begin{tabular}{|c|l|cc|}
\hline No & \multicolumn{1}{|c|}{ Persyaratan } & \multicolumn{2}{c|}{ Harga } \\
\hline 1 & Akta Pendirian CV & $\mathrm{Rp}$ & 1.500 .000 \\
\hline 2 & Pengesahan Pengadilan Negeri & $\mathrm{Rp}$ & 1.000 .000 \\
\hline 3 & Surat Keterangan Domisili & $\mathrm{Rp}$ & 100.000 \\
\hline 4 & NPWP Perusahaan & $\mathrm{Rp}$ & 0 \\
\hline 5 & SIUP & $\mathrm{Rp}$ & 500.000 \\
\hline 6 & TDP & $\mathrm{Rp}$ & 300.000 \\
\hline & Total Pengurusan Izin Usaha & $\mathrm{Rp}$ & 3.400 .000 \\
\hline
\end{tabular}

Sumber: Data Primer. diolah

Dari Tabel 4.13. di atas dapat dilihat tentang proyeksi biaya pengurusan izin usaha Ide Kreatif. Hal ini dikarenakan untuk ke depannya. Ide Kreatif menginginkan memiliki badan usaha CV dalam usahanya. Dengan demikian. diperlukan biaya untuk mengurus segala persyaratannya. 
Tabel 4.14.

Total Project Cost Ide Kreatif

\begin{tabular}{|l|lr|}
\hline \multicolumn{3}{|c|}{ INVESTASI AWAL } \\
\hline Pembayaran Sewa Kantor & $\mathrm{Rp}$ & 25.000 .000 \\
\hline Peralatan & $\mathrm{Rp}$ & 70.000 .000 \\
\hline Pengurusan Izin Usaha & $\mathrm{Rp}$ & 3.400 .000 \\
\hline \multicolumn{2}{|c|}{ Total Investasi Awal } & $\mathrm{Rp}$ \\
\hline \multicolumn{2}{|c|}{ MODAL KERJA } \\
\hline Kas & $\mathrm{Rp}$ \\
\hline Persediaan & $\mathrm{Rp}$ & 7.400 .000 \\
\hline Perlengkapan & $\mathrm{Rp}$ & 4.026 .250 \\
\hline \multicolumn{2}{|c|}{ Total Modal Kerja } & $\mathrm{Rp}$ \\
\hline \multicolumn{2}{|c|}{ TOTAL PROJECT COST } & $\mathrm{Rp}$ \\
\hline
\end{tabular}

Sumber: Data Primer. diolah

Dengan total project cost. diasumsikan persediaan buku sebagai berikut.

Tabel 4.15.

Asumsi Persediaan Buku Ide Kreatif Tahun 2014

\begin{tabular}{|c|c|c|c|c|c|}
\hline No & Jenis Buku & Jumlah & Jumlah Judul & Harga Satuan & Total \\
\hline 1 & Buku Motivasi & 5000 & 5 & Rp 13.000 & $\operatorname{Rp} 65.000 .000$ \\
\hline 2 & Buku Novel & 2000 & 2 & Rp 10.000 & Rp 20.000.000 \\
\hline 3 & Buku Nonfiksi & 1000 & 1 & Rp 15.000 & $\operatorname{Rp} 15.000 .000$ \\
\hline 4 & Buku Agama & 1000 & 1 & Rp 13.000 & $\mathrm{Rp} 13.000 .000$ \\
\hline 5 & Buku Anak-Anak & 1000 & 1 & $\mathrm{Rp} 10.000$ & Rp 10.000.000 \\
\hline 6 & Buku Pelajaran & 2000 & 2 & $\mathrm{Rp} 10.000$ & $\mathrm{Rp} 20.000 .000$ \\
\hline 7 & Buku Biografi & 1000 & 1 & $\mathrm{Rp} 15.000$ & Rp 15.000.000 \\
\hline \multicolumn{5}{|c|}{ Total Produk Ide Kreatif Tahun 2014} & Rp 158.000 .000 \\
\hline
\end{tabular}

Sumber: Data Primer. diolah

Tabel 4.16.

Asumsi Persediaan Buku Ide Kreatif Tahun 2015

\begin{tabular}{|c|l|c|c|cr|cc|}
\hline No & Jenis Buku & Jumlah & Jumlah Judul & Harga Satuan & \multicolumn{2}{|c|}{ Total } \\
\hline 1 & Buku Motivasi & 7500 & 5 & $\mathrm{Rp}$ & 14.625 & $\mathrm{Rp}$ & 109.687 .500 \\
\hline 2 & Buku Novel & 3000 & 2 & $\mathrm{Rp}$ & 11.250 & $\mathrm{Rp}$ & 33.750 .000 \\
\hline 3 & Buku Nonfiksi & 1500 & 1 & $\mathrm{Rp}$ & 16.875 & $\mathrm{Rp}$ & 25.312 .500 \\
\hline 4 & Buku Agama & 1500 & 1 & $\mathrm{Rp}$ & 14.625 & $\mathrm{Rp}$ & 21.937 .500 \\
\hline 5 & Buku Anak-Anak & 1500 & 1 & $\mathrm{Rp}$ & 11.250 & $\mathrm{Rp}$ & 16.875 .000 \\
\hline 6 & Buku Pelajaran & 3000 & 2 & $\mathrm{Rp}$ & 11.250 & $\mathrm{Rp}$ & 33.750 .000 \\
\hline 7 & Buku Biografi & 1500 & 1 & $\mathrm{Rp}$ & 16.875 & $\mathrm{Rp}$ & 25.312 .500 \\
\hline
\end{tabular}


Sumber: Data Primer. diolah

Tabel 4.17.

Asumsi Persediaan Buku Ide Kreatif Tahun 2016

\begin{tabular}{|c|c|c|c|c|c|c|}
\hline No & Jenis Buku & Jumlah & Jumlah Judul & \multicolumn{2}{|c|}{ Harga Satuan } & Total \\
\hline 1 & Buku Motivasi & 10000 & 5 & $\mathrm{Rp}$ & 19.500 & Rp 195.000.000 \\
\hline 2 & Buku Novel & 4000 & 2 & $\mathrm{Rp}$ & 15.000 & Rp $\quad 60.000 .000$ \\
\hline 3 & Buku Nonfiksi & 2000 & 1 & $\mathrm{Rp}$ & 22.500 & Rp 45.000 .000 \\
\hline 4 & Buku Agama & 2000 & 1 & $\mathrm{Rp}$ & 19.500 & $\mathrm{Rp} \quad 39.000 .000$ \\
\hline 5 & Buku Anak-Anak & 2000 & 1 & $\mathrm{Rp}$ & 15.000 & $\mathrm{Rp} \quad 30.000 .000$ \\
\hline 6 & Buku Pelajaran & 4000 & 2 & $\mathrm{Rp}$ & 15.000 & Rp $\quad 60.000 .000$ \\
\hline 7 & Buku Biografi & 2000 & 1 & $\mathrm{Rp}$ & 22.500 & $\mathrm{Rp} \quad 45.000 .000$ \\
\hline \multicolumn{6}{|c|}{ Total Produk Ide Kreatif Tahun 2014} & Rp 474.000.000 \\
\hline
\end{tabular}

Sumber: Data Primer. diolah

Adapun asumsi persediaan buku Ide Kreatif di tahun 2014 mengacu pada hasil wawancara dengan SDM pada CV. Karya Utama yang memproduksi buku sendiri.

\section{Penjualan}

Adapun proyeksi penjualan produk Ide Kreatif ini nantinya akan dibuat per tahun. dimulai pada tahun 2014 hingga tahun 2016. Peningkatan harga jual adalah 4\% sesuai dengan proyeksi inflasi pada tahun 2015. yakni 4\%. Angka proyeksi ini ditetapkan dalam Peraturan menteri keuangan (PMK) Nomor 66/PMK.011/2012. Kemudian untuk proyeksi inflasi tahun 2016 belum ditetapkan oleh pemerintah. sehingga dalam penelitian ini ditetapkan dengan menggunakan rata-rata inflasi dari tahun 2010 hingga tahun 2015. yakni sekitar $4.675 \%$. Adapun keterangan kenaikan inflasi tersebut dapat dilihat pada Tabel 4.18. berikut.

Tabel 4.18.

Inflasi di Indonesia Tahun 2010 - Tahun 2015

\begin{tabular}{|c|c|c|c|c|c|}
\hline 2010 & 2011 & 2012 & 2013 & 2014 & 2015 \\
\hline $6.96 \%$ & $3.79 \%$ & $4.3 \%$ & $4.5 \%$ & $4.5 \%$ & $4 \%$ \\
\hline
\end{tabular}

Sumber: Bank Indonesia (2013) 
Dengan demikian. maka proyeksi penjualan produk Ide Kreatif menurut jenis buku masing-masing dapat dilihat sebagai berikut.

Tabel 4.19.

Proyeksi Penjualan Buku Motivasi Ide Kreatif

\begin{tabular}{|c|c|c|c|}
\hline & \multicolumn{3}{|c|}{ Tahun } \\
\hline & 2014 & 2015 & 2016 \\
\hline Volume & 5000 & 7500 & 10000 \\
\hline Harga Jual & 30.000 & 37.500 & $\mathrm{Rp} \quad 56.250$ \\
\hline Nilai Penjualan & Rp 150.000 .000 & $\mathrm{Rp} 281.250 .000$ & Rp 562.500.000 \\
\hline
\end{tabular}

Sumber: Data Primer. diolah

Tabel 4.20.

Proyeksi Penjualan Buku Novel Ide Kreatif

\begin{tabular}{|c|c|c|c|c|c|c|}
\hline & \multicolumn{6}{|c|}{ Tahun } \\
\hline & & 2014 & & 15 & & 16 \\
\hline Volume & & 2000 & & 00 & & 00 \\
\hline Harga Jual & $\mathrm{Rp}$ & 25.000 & $\mathrm{Rp}$ & 31.250 & $\mathrm{Rp}$ & 46.875 \\
\hline Nilai Penjualan & $\mathrm{Rp}$ & 50.000 .000 & & 750.000 & $\mathrm{Rp}$ & .500 .000 \\
\hline
\end{tabular}

Sumber: Data Primer. diolah

Tabel 4.21.

Proyeksi Penjualan Buku Nonfiksi Ide Kreatif

\begin{tabular}{|c|c|c|c|c|c|c|}
\hline & \multicolumn{6}{|c|}{ Tahun } \\
\hline & & & & 15 & & 16 \\
\hline Volume & & & & 00 & & 00 \\
\hline Harga Jual & $\mathrm{Rp}$ & 35.000 & & 43.750 & $\mathrm{Rp}$ & 65.625 \\
\hline Nilai Penjualan & $\mathrm{Rp}$ & 000.000 & $\mathrm{Rp}$ & 625.000 & $\mathrm{Rp}$ & .250 .000 \\
\hline
\end{tabular}

Sumber: Data Primer. diolah

Tabel 4.22.

Proyeksi Penjualan Buku Agama Ide Kreatif

\begin{tabular}{|c|c|c|c|c|c|}
\hline & \multicolumn{5}{|c|}{ Tahun } \\
\hline & & 2014 & & 2015 & 2016 \\
\hline Volume & & 1000 & & 1500 & 2000 \\
\hline Harga Jual & $\mathrm{Rp}$ & 30.000 & $\mathrm{Rp}$ & 37.500 & 56.250 \\
\hline Nilai Penjualan & $\mathrm{Rp}$ & 30.000 .000 & $\mathrm{Rp}$ & 56.250 .000 & $\operatorname{Rp} 112.500 .000$ \\
\hline
\end{tabular}

Sumber: Data Primer. diolah 
Tabel 4.23.

Proyeksi Penjualan Buku Anak-Anak Ide Kreatif

\begin{tabular}{|l|rr|rr|rr|}
\hline \multirow{2}{*}{} & \multicolumn{5}{|c|}{ Tahun } \\
\cline { 2 - 7 } & \multicolumn{2}{|c|}{$\mathbf{2 0 1 4}$} & \multicolumn{2}{|c|}{$\mathbf{2 0 1 5}$} & \multicolumn{2}{c|}{$\mathbf{2 0 1 6}$} \\
\hline Volume & \multicolumn{2}{|c|}{1000} & \multicolumn{2}{c|}{1500} & \multicolumn{2}{c|}{2000} \\
\hline Harga Jual & $\mathrm{Rp}$ & 25.000 & $\mathrm{Rp}$ & 31.250 & $\mathrm{Rp}$ & 46.875 \\
\hline Nilai Penjualan & $\mathrm{Rp}$ & 25.000 .000 & $\mathrm{Rp}$ & 46.875 .000 & $\mathrm{Rp}$ & 93.750 .000 \\
\hline
\end{tabular}

Sumber: Data Primer. diolah

Tabel 4.24.

Proyeksi Penjualan Buku Pelajaran Ide Kreatif

\begin{tabular}{|l|rr|rr|rr|}
\hline & \multicolumn{4}{|c|}{ Tahun } \\
\cline { 2 - 6 } & \multicolumn{2}{|c|}{$\mathbf{2 0 1 4}$} & \multicolumn{2}{c|}{$\mathbf{2 0 1 5}$} & \multicolumn{2}{c|}{$\mathbf{2 0 1 6}$} \\
\hline Volume & \multicolumn{2}{|c|}{2000} & \multicolumn{2}{c|}{3000} & \multicolumn{2}{c|}{4000} \\
\hline Harga Jual & $\mathrm{Rp}$ & 25.000 & $\mathrm{Rp}$ & 31.250 & $\mathrm{Rp}$ & 46.875 \\
\hline Nilai Penjualan & $\mathrm{Rp}$ & 50.000 .000 & $\mathrm{Rp}$ & 93.750 .000 & $\mathrm{Rp} 187.500 .000$ \\
\hline
\end{tabular}

cSumber: Data Primer. diolah

Tabel 4.25.

Proyeksi Penjualan Buku Biografi Ide Kreatif

\begin{tabular}{|l|rr|rr|rr|}
\hline \multirow{2}{*}{} & \multicolumn{4}{|c|}{ Tahun } \\
\cline { 2 - 7 } & \multicolumn{2}{|c|}{$\mathbf{2 0 1 4}$} & \multicolumn{2}{c|}{$\mathbf{2 0 1 5}$} & \multicolumn{2}{c|}{$\mathbf{2 0 1 6}$} \\
\hline Volume & \multicolumn{2}{|c|}{1000} & \multicolumn{2}{c|}{1500} & \multicolumn{2}{c|}{2000} \\
\hline Harga Jual & $\mathrm{Rp}$ & 35.000 & $\mathrm{Rp}$ & 43.750 & $\mathrm{Rp}$ & 65.625 \\
\hline Nilai Penjualan & $\mathrm{Rp}$ & 35.000 .000 & $\mathrm{Rp}$ & 65.625 .000 & $\mathrm{Rp} 131.250 .000$ \\
\hline
\end{tabular}

Sumber: Data Primer. diolah

Dari beberapa tabel proyeksi penjualan di atas. maka total proyeksi penjualan

Ide Kreatif dapat dilihat pada Tabel 4.26. berikut.

Tabel 4.26.

Total Proyeksi Penjualan Ide Kreatif Tahun 2014 - Tahun 2016

\begin{tabular}{|c|cc|}
\hline Tahun & \multicolumn{2}{|c|}{ Total Penjualan } \\
\hline 2014 & $\mathrm{Rp}$ & 375.000 .000 \\
\hline 2015 & $\mathrm{Rp}$ & 703.125 .000 \\
\hline 2016 & $\mathrm{Rp}$ & 1.406 .250 .000 \\
\hline
\end{tabular}

Sumber: Data Primer. diolah

\section{Harga Pokok Penjualan (HPP)}

Adapun komponen yang terkandung dalam harga pokok penjualan merupakan persediaan barang dagang awal. pembelian kredit dan tunai. beban angkut pembelian. retur pembelian. potongan pembelian. persediaan barang 
dagang akhir. biaya transportasi. dan biaya komunikasi. Dalam hal ini. pembelian yang dimaksud adalah pembelian naskah yang dilakukan oleh Ide Kreatif yang kemudian akan dicetak. diterbitkan. kemudian dijual oleh Ide Kreatif pada agen dan distributor yang menjadi relasi bisnis Ide Kreatif. Penjelasan HPP dapat dilihat pada beberapa tabel berikut.

Tabel 4.27.

Harga Pokok Penjualan Ide Kreatif Tahun 2014

\begin{tabular}{|c|c|c|c|}
\hline Persediaan barang dagang awal & \multirow{5}{*}{$\begin{array}{lc}\mathrm{Rp} & 158.000 .000 \\
\mathrm{Rp} & - \\
\mathrm{Rp} & - \\
\mathrm{Rp} & - \\
\end{array}$} & \multirow[t]{5}{*}{$\mathrm{Rp}$} & \multirow[t]{5}{*}{-} \\
\hline Pembelian barang dagang & & & \\
\hline Beban angkut pembelian & & & \\
\hline Retur Pembelian & & & \\
\hline Potongan Pembelian & & & \\
\hline Pembelian bersih & & $\mathrm{Rp}$ & 158.000 .000 \\
\hline Barang tersedia untuk dijual & & \multirow{2}{*}{\multicolumn{2}{|c|}{$\begin{array}{ll}\mathrm{Rp} & 158.000 .000 \\
\mathrm{Rp} & (15.800 .000) \\
\end{array}$}} \\
\hline Persediaan barang dagang akhir & & & \\
\hline Harga Pokok Pembelian & & \multirow{3}{*}{$\begin{array}{l}\mathrm{Rp} \\
\mathrm{Rp} \\
\mathrm{Rp}\end{array}$} & 142.200 .000 \\
\hline Biaya Transportasi & & & 2.100 .000 \\
\hline Biaya Promosi & & & 10.000 .000 \\
\hline Harga Pokok Penjualan & & \multicolumn{2}{|c|}{$\begin{array}{ll}\mathrm{Rp} & 154.300 .000 \\
\end{array}$} \\
\hline
\end{tabular}

Sumber: Data Primer. diolah

Tabel 4.28.

Harga Pokok Penjualan Ide Kreatif Tahun 2015

\begin{tabular}{|c|c|c|}
\hline \multirow{2}{*}{$\begin{array}{l}\text { Persediaan barang dagang awal } \\
\text { Pembelian barang dagang }\end{array}$} & \multirow{5}{*}{$\begin{array}{lc}\mathrm{Rp} & 266.625 .000 \\
\mathrm{Rp} & - \\
\mathrm{Rp} & - \\
\mathrm{Rp} & - \\
\end{array}$} & \multirow[t]{5}{*}{$\mathrm{Rp} \quad 15.800 .000$} \\
\hline & & \\
\hline Beban angkut pembelian & & \\
\hline Retur Pembelian & & \\
\hline Potongan Pembelian & & \\
\hline Pembelian bersih & & 266.625 .000 \\
\hline Barang tersedia untuk dijual & & $\mathrm{Rp} \quad 282.425 .000$ \\
\hline Persediaan barang dagang akhir & & $\mathrm{Rp} \quad(39.993 .750)$ \\
\hline Harga Pokok Pembelian & & $\mathrm{Rp} \quad 242.431 .250$ \\
\hline Biaya Transportasi & & 3.300 .000 \\
\hline Biaya Promosi & & 15.000 .000 \\
\hline Harga Pokok Penjualan & & $\operatorname{Rp} \quad 260.731 .250$ \\
\hline
\end{tabular}

Sumber: Data Primer. diolah 
Tabel 4.29.

Harga Pokok Penjualan Ide Kreatif Tahun 2016

\begin{tabular}{|c|c|c|c|}
\hline Persediaan barang dagang awal & \multirow{5}{*}{$\begin{array}{lc}\text { Rp } & 474.000 .000 \\
R p & - \\
R p & - \\
R p & -\end{array}$} & \multirow[t]{5}{*}{$\mathrm{Rp}$} & \multirow[t]{5}{*}{39.993 .750} \\
\hline Pembelian barang dagang & & & \\
\hline Beban angkut pembelian & & & \\
\hline Retur Pembelian & & & \\
\hline Potongan Pembelian & & & \\
\hline Pembelian bersih & & $\mathrm{Rp}$ & 474.000 .000 \\
\hline Barang tersedia untuk dijual & & $\mathrm{Rp}$ & 513.993 .750 \\
\hline Persediaan barang dagang akhir & & $\mathrm{Rp}$ & $(94.800 .000)$ \\
\hline Harga Pokok Pembelian & & $\mathrm{Rp}$ & 419.193 .750 \\
\hline Biaya Transportasi & & $\mathrm{Rp}$ & 5.110 .000 \\
\hline Biaya Promosi & & $\mathrm{Rp}$ & 20.000 .000 \\
\hline Harga Pokok Penjualan & & $\mathrm{Rp}$ & 444.303 .750 \\
\hline
\end{tabular}

Sumber: Data Primer. diolah

\section{Biaya Usaha}

Biaya usaha yang digunakan dalam Ide Kreatif dapat dibagi menjadi beberapa bagian. antara lain:

a. Biaya Listrik

Jumlah hari kerja dalam seminggu Ide Kreatif adalah 5 hari. Dengan demikian. dalam 1 tahun. asumsi hari kerja ada 261 hari. Adapun tarif listrik pada tahun 2014 belum ada rencana kenaikan oleh Dirjen Ketenagalistrikan Kementrian ESDM. Oleh karenanya. angka yang akan dipakai dalam perhitungan biaya listrik adalah Rp 1.145/kWh. Hal ini dikarenakan angka tersebut merupakan tarif dasar listrik kategori rumah tangga triwulan IV 2013 (Oktober - Desember). Akan tetapi untuk tahun 2015 dan 2016 proyeksi kenaikan diperkirakan 10\% untuk mengantisipasi kenaikan tarif dasar listrik. Adapun perhiitungan biaya listrik sebagai berikut: 
Tabel 4.30.

Proyeksi Kebutuhan Listrik Ide Kreatif

\begin{tabular}{|c|l|c|c|c|c|}
\hline No & \multicolumn{1}{|c|}{ Nama Alat } & Jumlah & $\begin{array}{c}\text { Daya per } \\
\text { Satuan (Watt) }\end{array}$ & $\begin{array}{c}\text { Lama } \\
\text { Pemakaian per } \\
\text { Tahun (Jam) }\end{array}$ & $\begin{array}{c}\text { Kebutuhan } \\
\text { Listrik per } \\
\text { Tahun (kWh) }\end{array}$ \\
\hline 1 & Lampu & 7 & 30 & 2.088 & 438.48 \\
\hline 2 & Mesin Jilid Buku & 1 & 470 & 522 & 245.34 \\
\hline 3 & Mesin Cetak Toko 820 & 1 & 250 & 783 & 195.75 \\
\hline 4 & Mesin Shrink Tunnel & 1 & 12.000 & 783 & 9.396 .00 \\
\hline 5 & $\begin{array}{l}\text { Mesin Potong Kertas 1 } \\
\text { Rim Tipe 868 }\end{array}$ & 1 & 500 & 522 & 261.00 \\
\hline 6 & Komputer & 2 & 250 & 2.088 & 1.044 .00 \\
\hline 7 & Kipas Angin & 2 & 50 & 2.088 & 208.80 \\
\hline 8 & AC & 3 & 1200 & 2.088 & 7516.80 \\
\hline \multicolumn{7}{|r|}{ Total Proyeksi Kebutuhan Listrik Ide Kreatif } \\
\hline
\end{tabular}

Sumber: Data Primer. diolah

Tabel 4.31.

Proyeksi Biaya Listrik Ide Kreatif

\begin{tabular}{|c|c|c|cc|}
\hline Tahun & Kebutuhan $(\mathbf{k W h})$ & Tarif per kWh & \multicolumn{2}{|c|}{ Biaya } \\
\hline 2014 & 11.580 .57 & 1.145 & $\mathrm{Rp}$ & 13.259 .753 \\
\hline 2015 & 11.580 .57 & 1.259 & $\mathrm{Rp}$ & 14.579 .938 \\
\hline 2016 & 11.580 .57 & 1.385 & $\mathrm{Rp}$ & 16.039 .089 \\
\hline
\end{tabular}

Sumber: Data Primer. diolah

b. Biaya Transportasi

Biaya transportasi yang dimaksudkan dalam penelitian ini adalah biaya yang dibutuhkan untuk menjalankan kegiatan operasional Ide Kreatif. khususnya biaya bahan bakar. Adapun kebutuhan bahan bakar ini digunakan tenaga kerja untuk menyuplai produk pada agen atau distributor yang ada di wilayah Sidoarjo dan Surabaya. ataupun kota lain yang masih terjangkau. Selain untuk pengiriman. biaya transportasi ini juga dapat digunakan untuk keperluan tenaga kerja lain yang membutuhkan keluar kantor. misal tenaga kerja produksi yang akan membeli kertas ataupun kebutuhan lainnya. Adapun perhitungannya dapat dilihat sebagai berikut: 
Tabel 4.32.

Proyeksi Biaya Transportasi Ide Kreatif

\begin{tabular}{|c|c|ll|ll|}
\hline Tahun & Kebutuhan per Tahun (Liter) & \multicolumn{2}{|c|}{ Tarif per Liter } & \multicolumn{2}{|c|}{ Jumlah } \\
\hline 2014 & 350 & $\mathrm{Rp}$ & 6.000 & $\mathrm{Rp}$ & 2.100 .000 \\
\hline 2015 & 500 & $\mathrm{Rp}$ & 6.600 & $\mathrm{Rp}$ & 3.300 .000 \\
\hline 2016 & 700 & $\mathrm{Rp}$ & 7.300 & $\mathrm{Rp}$ & 5.110 .000 \\
\hline
\end{tabular}

Sumber: Data Primer. diolah

c. Biaya Promosi

Biaya promosi disini lebih ditekankan pada biaya domain website resmi Ide Kreatif. Hal ini dikarenakan pembuatan website dilakukan sendiri. karena tenaga kerja Ide Kreatif memiliki kemampuan dalam bidang tersebut. Dengan demikian. Ide Kreatif hanya tinggal membayar domainnya. Selain itu. biaya promosi juga meliputi publikasi melalui brosur. Adapun proyeksi biaya promosi sebagai berikut:

Tabel 4.33.

Proyeksi Biaya Promosi Ide Kreatif

\begin{tabular}{|c|cc|}
\hline Tahun & \multicolumn{2}{|c|}{ Biaya Promosi } \\
\hline 2014 & $\mathrm{Rp}$ & 10.000 .000 \\
\hline 2015 & $\mathrm{Rp}$ & 15.000 .000 \\
\hline 2016 & $\mathrm{Rp}$ & 20.000 .000 \\
\hline
\end{tabular}

Sumber: Data Primer. diolah

d. Biaya Kompensasi Tenaga Kerja

Tenaga kerja yang dimaksud disini yaitu tenaga kerja pembuat desain dan produksi. yang kesemuanya berjumlah 5 orang. Adapun kompensasi yang dimaksudkan disini adalah gaji yang akan diterima. dimana akan disesuaikan dengan UMK Surabaya. Berikut perhitungannya. 
Tabel 4.34.

Pertumbuhan Besaran UMK Surabaya

\begin{tabular}{|c|c|c|}
\hline No & Tahun UMK Surabaya & $\begin{array}{c}\text { Besaran UMK } \\
(\mathbf{R p})\end{array}$ \\
\hline 1. & 2009 & 948.500 .00 \\
\hline 2. & 2010 & 1.031 .500 .00 \\
\hline 3. & 2011 & 1.115 .000 .00 \\
\hline 4. & 2012 & 1.257 .000 .00 \\
\hline 5. & 2013 & 1.740 .000 .00 \\
\hline
\end{tabular}

Sumber: Data Sekunder dari Disnakertransduk. diolah

Tabel 4.34.

Perhitungan Biaya Gaji Karyawan Ide Kreatif

\begin{tabular}{|c|c|c|c|c|}
\hline $\begin{array}{l}\text { Spesifikasi } \\
\text { Pekerjaan }\end{array}$ & Jumlah & $\begin{array}{c}\text { Total Gaji } 1 \\
\text { Bulan/Orang }\end{array}$ & $\begin{array}{c}\text { Total Gaji Per } \\
\text { Bulan }\end{array}$ & $\begin{array}{c}\text { Total Gaji Karyawan } \\
\text { Per Tahun }\end{array}$ \\
\hline Pembuat desain & 1 & $\mathrm{Rp} \quad 2.000 .000$ & 2.000 .000 & 24.000 .000 \\
\hline Produksi & 2 & 2.000 .000 & 4.000 .000 & 48.000 .000 \\
\hline Editor & 1 & 2.000 .000 & 2.000 .000 & 24.000 .000 \\
\hline Kurir & 1 & 2.000 .000 & 2.000 .000 & 24.000 .000 \\
\hline \multicolumn{4}{|c|}{ Jumlah Total Gaji Karyawan 1 Tahun } & 120.000 .000 \\
\hline
\end{tabular}

Sumber: Data Primer. diolah

Tabel 4.35.

Proyeksi Kenaikan Gaji Karyawan Ide Kreatif

\begin{tabular}{|c|cc|}
\hline Tahun & \multicolumn{2}{|c|}{ Kenaikan Gaji Karyawan } \\
\hline 2014 & $\mathrm{Rp}$ & 120.000 .000 \\
\hline 2015 & $\mathrm{Rp}$ & 132.000 .000 \\
\hline 2016 & $\mathrm{Rp}$ & 145.200 .000 \\
\hline
\end{tabular}

Sumber: Data Primer. diolah

e. Biaya Penyusutan

Penyusutan adalah sebuah proses alokasi biaya dari harga yang diperlukan untuk memperoleh aktiva tetap yang diimplementasikan sesuai dengan umur ekonomisnya. Adapun alokasi biaya tersebut diperlukan dikarenakan berkurangnya manfaat atas kemampuan aktiva secara periodik untuk menghasilkan pendapatan bagi aktiva yang cenderung menurun seiring dengan bertambahnya usia dari aktiva tersebut. Faktor-faktor yang mampu mempengaruhi besarnya penyusutan aktiva tetap antara lain: harga perolehan. nilai residu. dan umur ekonomis. Dalam penelitian ini. 
penghitungan biaya penyusutan Ide Kreatif menggunakan metode garis lurus.

Adapun perhitungan biaya penyusutan dapat dijelaskan sebagai berikut.

Tabel 4.36.

Perhitungan Biaya Penyusutan Ide Kreatif

\begin{tabular}{|c|l|c|cr|c|cr|}
\hline No & \multicolumn{1}{|c|}{ Nama Alat } & Jumlah & \multicolumn{2}{c|}{$\begin{array}{c}\text { Harga } \\
\text { Perolehan }\end{array}$} & \multicolumn{2}{c|}{$\begin{array}{c}\text { Umur } \\
\text { Ekonomis }\end{array}$} & \multicolumn{2}{c|}{$\begin{array}{c}\text { Biaya } \\
\text { Penyusutan }\end{array}$} \\
\hline 1 & Lampu & 7 & $\mathrm{Rp}$ & 50.000 & 3 tahun & $\mathrm{Rp}$ & 16.667 \\
\hline 2 & Mesin Jilid Buku & 1 & $\mathrm{Rp}$ & 8.700 .000 & 5 tahun & $\mathrm{Rp}$ & 1.740 .000 \\
\hline 3 & Mesin Cetak Toko 820 & 1 & $\mathrm{Rp} 34.000 .000$ & 5 tahun & $\mathrm{Rp}$ & 6.800 .000 \\
\hline 4 & Mesin Shrink Tunnel & 1 & $\mathrm{Rp} 24.500 .000$ & 5 tahun & $\mathrm{Rp}$ & 4.900 .000 \\
\hline & Mesin Potong Kertas 1 & 1 & $\mathrm{Rp}$ & 2.800 .000 & 5 tahun & $\mathrm{Rp}$ & 560.000 \\
\hline 5 & Rim Tipe 868 & 2 & $\mathrm{Rp}$ & 2.500 .000 & 3 tahun & $\mathrm{Rp}$ & 833.333 \\
\hline 6 & Komputer & 2 & $\mathrm{Rp}$ & 350.000 & 3 tahun & $\mathrm{Rp}$ & 116.667 \\
\hline 7 & Kipas Angin & 3 & $\mathrm{Rp} 2.000 .000$ & 3 tahun & $\mathrm{Rp}$ & 666.667 \\
\hline 8 & AC Total Biaya Penyusutan per Tahun & & $\mathrm{Rp} 15.633 .333$ \\
\hline \multicolumn{2}{|c|}{}
\end{tabular}

Sumber: Data Primer. diolah

f. Biaya Pajak

Tarif pajak yang digunakan oleh Ide Kreatif adalah tarif pajak yang berasal dari perhitungan laba bersih perusahaan. Tarif pajak yang dikenakan adalah tarif pajak badan untuk CV yaitu sebesar $25 \%$ sesuai dengan pasal 17 ayat 1b dan ayat 2a UU PPh 2008 untuk UKM. Khusus untuk Wajib Pajak Badan yang peredaran bruto setahun sampai dengan Rp50 Milyar mendapat fasilitas berupa pengurangan tarif sebesar 50\% menurut pasal 31E UU PPh 2008. Jadi pajak yang akan dibayarkan sebesar $12.5 \%$. 
5. Proyeksi Laporan Keuangan

Dalam penelitian ini. proyeksi laporan keuangan yang dibuat berupa 2 laporan. yaitu proyeksi laporan laba rugi dan proyeksi laporan arus kas. Adapun proyeksi laporan keuangan ini dibagi sebagai berikut:

a. Proyeksi Laporan Keuangan Kondisi Normal

Proyeksi laporan keuangan kondisi normal menggunakan asumsi volume penjualan sama dengan yang dijelaskan pada perhitungan awal. Dengan demikian. proyeksi laporan arus kas Ide Kreatif kondisi normal dapat dilihat berikut.

Tabel 4.38.

Proyeksi Laporan Arus Kas Kondisi Normal

\begin{tabular}{|l|r|r|r|r|}
\hline \multicolumn{1}{|c|}{ Keterangan } & \multicolumn{1}{c|}{$\begin{array}{c}\text { Masa } \\
\text { Investasi (Rp) }\end{array}$} & \multicolumn{1}{c|}{$\begin{array}{c}\text { 2014 } \\
\text { (Rp) }\end{array}$} & \multicolumn{1}{c|}{$\begin{array}{c}\text { 2015 } \\
\text { (Rp) }\end{array}$} & \multicolumn{1}{c|}{ (Rp) } \\
\hline Investasi Awal & & & & \\
\hline Net Working Capital (NWC) & 15.571 .250 & & & \\
\hline Project Cost & 113.971 .250 & & & \\
\hline \multicolumn{1}{|c|}{ Operating Cash Flow } & & & & \\
\hline Penjualan & & 375.000 .000 & 703.125 .000 & 1.406 .250 .000 \\
\hline Harga Pokok Penjualan & & $(154.300 .000)$ & $(260.731 .250)$ & $(444.303 .750)$ \\
\hline Biaya Gaji & & $(120.000 .000)$ & $(132.000 .000)$ & $(145.200 .000)$ \\
\hline Biaya Listrik & & $(13.259 .753)$ & $(14.579 .937)$ & $(16.039 .089)$ \\
\hline Biaya Transportasi & & $(2.100 .000)$ & $(3.300 .000)$ & $(5.110 .000)$ \\
\hline Biaya Promosi & & $(15.633 .333)$ & $(15.633 .333)$ & $(15.633 .333)$ \\
\hline Biaya Penyusutan & & 59.706 .914 & 261.880 .479 & 759.963 .828 \\
\hline Laba Sebelum Pajak (EBT) & & 7.463 .364 & 32.735 .060 & 94.995 .478 \\
\hline Pajak & & 52.243 .550 & 229.145 .419 & 664.968 .349 \\
\hline Laba Sesudah Pajak (EAT) & & & & \\
\hline & & & & \\
\hline Arus Kas Operasi & 113.971 .250 & 52.243 .550 & 229.145 .419 & 664.968 .349 \\
\hline Investasi pada NWC & & & & 15.571 .250 \\
\hline Terminal Cash Flow & & & & \\
\hline & & & & \\
\hline Total Arus Kas & $(113.971 .250)$ & 52.243 .550 & 229.145 .419 & 680.539 .599 \\
\hline Kas Akhir & & $(61.727 .700)$ & 167.417 .720 & 847.957 .319 \\
\hline Sumber: Data Primer & & &
\end{tabular}

Sumber: Data Primer. Diolah 
Tabel 4.39.

Proyeksi Laporan Laba Rugi Ide Kreatif Kondisi Normal

\begin{tabular}{|c|c|c|c|}
\hline & $\begin{array}{l}2014 \\
\text { (Rp) }\end{array}$ & $\begin{array}{l}2015 \\
\text { (Rp) }\end{array}$ & $\begin{array}{l}2016 \\
\text { (Rp) }\end{array}$ \\
\hline \multicolumn{4}{|l|}{ PENDAPATAN } \\
\hline Penjualan & 375.000 .000 & 703.125 .000 & 1.406 .250 .000 \\
\hline Harga Pokok Penjualan & 154.300 .000 & 260.731 .250 & 444.303 .750 \\
\hline Laba Kotor & 220.700 .000 & 442.393 .750 & 961.946 .250 \\
\hline \multicolumn{4}{|l|}{ BEBAN USAHA } \\
\hline Beban Gaji & 120.000 .000 & 132.000 .000 & 145.200 .000 \\
\hline Beban Listrik & 13.259 .753 & 14.579 .938 & 16.039 .089 \\
\hline Beban Transportasi & 2.100 .000 & 3.300 .000 & 5.110 .000 \\
\hline Beban Promosi & 10.000 .000 & 15.000 .000 & 20.000 .000 \\
\hline Beban Penyusutan & 15.633 .333 & 15.633 .333 & 15.633 .333 \\
\hline Total Biaya Usaha & 160.993 .086 & 180.513 .271 & 201.982 .422 \\
\hline Laba/Rugi Sebelum Pajak & 59.706 .914 & 261.880 .479 & 759.963 .828 \\
\hline Pajak & 7.463 .364 & 32.735 .060 & 94.995 .478 \\
\hline Laba/Rugi Setelah Pajak & 52.243 .550 & 229.145 .419 & 664.968 .349 \\
\hline
\end{tabular}

Sumber: Data Primer. diolah

Dari kedua proyeksi laporan keuangan di atas. maka selanjutnya akan

dihitung kriteria penilaian investasi secara finansial yang terdiri dari:

1) Payback Period (PP)

Tabel 4.40.

Perhitungan Payback Period Ide Kreatif Kondisi Normal

\begin{tabular}{|l|l|l|}
\hline \multicolumn{1}{|c|}{ Keterangan } & Jumlah & Akumulasi \\
\hline Kas Keluar & $\mathrm{Rp}(113.971 .250)$ & $\mathrm{Rp}(113.971 .250)$ \\
\hline Kas Masuk Tahun 2014 & $\mathrm{Rp} 52.243 .550$ & $\mathrm{Rp} \mathrm{(61.727.700)}$ \\
\hline Kas Masuk Tahun 2015 & $\mathrm{Rp} 229.145 .419$ & $\mathrm{Rp} \mathrm{167.417.720}$ \\
\hline Kas Masuk Tahun 2016 & $\mathrm{Rp} \quad 680.539 .599$ & $\mathrm{Rp} \mathrm{847.957.319}$ \\
\hline
\end{tabular}

Sumber: Data Primer. Diolah

Perhitungan Payback Period:

$1+(\operatorname{Rp} 61.727 .700 / \operatorname{Rp} 229.145 .419)=1$ tahun +0.27 tahun

0.27 tahun $\mathrm{x} 12$ bulan $=3.23$ bulan $=3$ bulan +0.23 bulan

0.23 bulan $\mathrm{x} 30$ hari $=7$ hari $\rightarrow 1$ tahun 3 bulan 7 hari 
Jadi. usaha pengembangan Ide Kreatif memerlukan waktu 1 tahun 3 bulan 7 hari untuk mengembalikan investasi awal modalnya. Waktu tersebut kurang dari 3 tahun. sehingga rencana pengembangan bisnis layak untuk dilakukan.

2) Net Present Value (NPV)

Dalam penelitian ini. perhitungan NPV menggunakan Microsoft Excel yang datanya dapat dilihat dari Tabel 4.41. berikut.

Tabel 4.41.

Perhitungan Data NPV Ide Kreatif Kondisi Normal

\begin{tabular}{|c|c|}
\hline Keterangan & Jumlah \\
\hline Kas Keluar & $\mathrm{Rp}(113.971 .250)$ \\
\hline Kas Masuk Tahun 2014 & Rp 52.243 .550 \\
\hline Kas Masuk Tahun 2015 & Rp 229.145 .419 \\
\hline Kas Masuk Tahun 2016 & $\begin{array}{ll}\mathrm{Rp} & 680.539 .599 \\
\end{array}$ \\
\hline NPV & Rp 563.847.806.86 \\
\hline
\end{tabular}

Sumber: Data Primer. diolah

NPV yang diperoleh sebesar 563.847.806.86 yang berarti bahwa rencana pengembangan bisnis dapat dilakukan. Hal ini dibuktikan dengan nilai angka NPV lebih besar dari 0 (bertanda positif). sehingga dapat dikatakan layak.

3) Profitability Index (PI)

Dalam penelitian ini. perhitungan PI juga menggunakan Microsoft Excel yang datanya sebagai berikut.

Tabel 4.42.

Perhitungan Data PI Ide Kreatif Kondisi Normal

\begin{tabular}{|l|c|}
\hline \multicolumn{1}{|c|}{ Keterangan } & \multicolumn{2}{c|}{ Jumlah } \\
\hline Kas Keluar & Rp (113.971.250) \\
\hline Kas Masuk Tahun 2014 & Rp 52.243 .550 \\
\hline Kas Masuk Tahun 2015 & $\operatorname{Rp~} 229.145 .419$ \\
\hline Kas Masuk Tahun 2016 & $\operatorname{Rp~} 680.539 .599$ \\
\hline \multicolumn{1}{|c|}{ PI } & \multicolumn{2}{|c|}{5.947} \\
\hline
\end{tabular}

Sumber: Data Primer. diolah 
Nilai PI yang diperoleh sebesar 5.947 yang menunjukkan bahwa penerimaan kas lebih besar 5.947 kali daripada pengeluaran. Dengan demikian. dapat disimpulkan bahwa rencana pengembangan bisnis Ide Kreatif dapat dilakukan karena nilai PI lebih besar daripada 1.

4) Internal Rate of Return

Perhitungan nilai IRR dalam penelitian ini juga dilakukan menggunakan Microsoft Excel pada Tabel 4.43. berikut.

Tabel 4.43.

Perhitungan Data IRR Ide Kreatif Skenario Normal

\begin{tabular}{|c|c|}
\hline Keterangan & Jumlah \\
\hline Kas Keluar & $\operatorname{Rp}(113.971 .250)$ \\
\hline Kas Masuk Tahun 2014 & $\mathrm{Rp} \quad 52.243 .550$ \\
\hline Kas Masuk Tahun 2015 & Rp 229.145 .419 \\
\hline Kas Masuk Tahun 2016 & $\begin{array}{ll}\mathrm{Rp} & 680.539 .599 \\
\end{array}$ \\
\hline IRR & $137 \%$ \\
\hline
\end{tabular}

Sumber: Data Primer. diolah

Dari Tabel 4.43. di atas dapat dilihat bahwa IRR yang diperoleh mencapai $137 \%$. Tingkat bunga IRR lebih besar jika dibandingkan dengan suku bunga kredit retail dari BCA yaitu sebesar $10.60 \%$ per tahun. Dengan demikian dapat disimpulkan bahwa rencana pengembangan bisnis Ide Kreatif dapat dilakukan karena memberikan tingkat pengembalian lebih tinggi daripada suku bunga kredit.

b. Proyeksi Laporan Keuangan Kondisi Optimis

Kondisi skenario optimis menggunakan asumsi penjualan mampu melebihi ekspektasi perhitungan awal dan terjadi peningkatan sebesar $7 \%$ berdasarkan wawancara yang dilakukan dengan CV. Karya Utama. Dengan demikian. proyeksi laporan keuangan kondisi optimis sebagai berikut. 
Tabel 4.44.

Proyeksi Laporan Arus Kas Kondisi Optimis

\begin{tabular}{|l|r|r|r|r|}
\hline \multicolumn{1}{|c|}{ Keterangan } & Investasi (Rp) & 2014 (Rp) & \multicolumn{1}{c|}{$\mathbf{2 0 1 5}(\mathbf{R p )}$} & \multicolumn{1}{c|}{$\mathbf{2 0 1 6}(\mathbf{R p )}$} \\
\hline Investasi Awal & & & & \\
\hline Net Working Capital & 98.400 .000 & & & \\
\hline Project Cost & 15.571 .250 & & & \\
\hline \multicolumn{1}{|c|}{ Operating Cash Flow } & 13.971 .250 & & & \\
\hline Penjualan & & & & \\
\hline Harga Pokok Penjualan & & $(154.300 .000)$ & $(260.731 .250)$ & $(444.303 .750)$ \\
\hline Biaya Gaji & & $(120.000 .000)$ & $(132.000 .000)$ & $(145.200 .000)$ \\
\hline Biaya Listrik & & $(13.259 .753)$ & $(14.579 .938)$ & $(16.039 .089)$ \\
\hline Biaya Transportasi & & $(10.000 .000)$ & $(15.000 .000)$ & $(20.000 .000)$ \\
\hline Biaya Promosi & & $(15.633 .333)$ & $(15.633 .333)$ & $(15.633 .333)$ \\
\hline Biaya Penyusutan & & 85.956 .914 & 311.099 .229 & 858.401 .328 \\
\hline Laba Sebelum Pajak (EBT) & & 10.744 .614 & 38.887 .404 & 107.300 .166 \\
\hline Pajak & & 75.212 .300 & 272.211 .826 & 751.101 .162 \\
\hline Laba Sesudah Pajak (EAT) & & & & 751.101 .162 \\
\hline Arus Kas Operasi & 113.971 .250 & 75.212 .300 & 272.211 .826 & 15.571 .250 \\
\hline Investasi pada NWC & & & & \\
\hline Terminal Cash Flow & & 75.212 .300 & 272.211 .826 & 766.672 .412 \\
\hline Total Arus Kas & $(113.971 .250)$ & $(38.758 .950)$ & 233.452 .876 & 1.000 .125 .287 \\
\hline Kas Akhir & $(113.971 .250)$ & & &
\end{tabular}

Sumber: Data Primer. Diolah

Tabel 4.45.

Proyeksi Laporan Laba Rugi Ide Kreatif Kondisi Optimis

\begin{tabular}{|l|r|r|r|}
\hline & \multicolumn{1}{|c|}{$\begin{array}{c}2014 \\
(\mathrm{Rp})\end{array}$} & \multicolumn{1}{c|}{$\begin{array}{c}2015 \\
(\mathrm{Rp})\end{array}$} & \multicolumn{1}{c|}{$\begin{array}{c}2016 \\
(\mathrm{Rp})\end{array}$} \\
\hline \multicolumn{1}{|c|}{ PENDAPATAN } & & & \\
\hline Penjualan & 401.250 .000 & 752.343 .750 & 1.504 .687 .500 \\
\hline Harga Pokok Penjualan & 154.300 .000 & 260.731 .250 & 444.303 .750 \\
\hline Laba Kotor & 246.950 .000 & 491.612 .500 & 1.060 .383 .750 \\
\hline \multicolumn{1}{|c|}{ BEBAN USAHA } & & & \\
\hline Beban Gaji & 120.000 .000 & 132.000 .000 & 145.200 .000 \\
\hline Beban Listrik & 13.259 .753 & 14.579 .938 & 16.039 .089 \\
\hline Beban Transportasi & 2.100 .000 & 3.300 .000 & 5.110 .000 \\
\hline Beban Promosi & 10.000 .000 & 15.000 .000 & 20.000 .000 \\
\hline Beban Penyusutan & 15.633 .333 & 15.633 .333 & 15.633 .333 \\
\hline Total Biaya Usaha & 160.993 .086 & 180.513 .271 & 201.982 .422 \\
\hline Laba/Rugi Sebelum Pajak & 85.956 .914 & 311.099 .229 & 858.401 .328 \\
\hline Pajak & 10.744 .614 & 38.887 .404 & 107.300 .166 \\
\hline Laba/Rugi Setelah Pajak & 75.212 .300 & 272.211 .826 & 751.101 .162 \\
\hline Sumber: Data Primer. Diolah & & & \\
\hline
\end{tabular}

Sumber: Data Primer. Diolah 
Dari kedua proyeksi laporan keuangan di atas. maka selanjutnya akan dihitung kriteria penilaian investasi secara finansial yang terdiri dari:

1) Payback Period (PP)

Tabel 4.46.

Perhitungan Payback Period Ide Kreatif Kondisi Normal

\begin{tabular}{|l|lr|l|}
\hline \multicolumn{1}{|c|}{ Keterangan } & \multicolumn{2}{c|}{ Jumlah } & \multicolumn{1}{c|}{ Akumulasi } \\
\hline Kas Keluar & $\mathrm{Rp}$ & $(113.971 .250)$ & $\mathrm{Rp} \mathrm{(113.971.250)}$ \\
\hline Kas Keluar & $\mathrm{Rp}$ & 75.212 .300 & $\mathrm{Rp}(38.758 .950)$ \\
\hline Kas Masuk Tahun 2015 & $\mathrm{Rp}$ & 272.211 .826 & $\mathrm{Rp} 233.452 .876$ \\
\hline Kas Masuk Tahun 2016 & $\mathrm{Rp}$ & 766.672 .412 & $\mathrm{Rp} \mathrm{1.000.125.287}$ \\
\hline
\end{tabular}

Sumber: Data Primer. Diolah

Perhitungan Payback Period:

$1+(\operatorname{Rp} 38.758 .950 / \operatorname{Rp} 272.211 .826)=1$ tahun +0.14 tahun

0.14 tahun $\mathrm{x} 12$ bulan $=1.71$ bulan $=1$ bulan +0.71 bulan

0.71 bulan $\mathrm{x} 30$ hari $=21$ hari $\rightarrow 1$ tahun 1 bulan 21 hari

Jadi. usaha pengembangan Ide Kreatif memerlukan waktu 1 tahun 1

bulan 21 hari untuk mengembalikan investasi awal modalnya. Waktu

tersebut kurang dari 3 tahun. sehingga rencana pengembangan bisnis

layak untuk dilakukan.

2) Net Present Value (NPV)

Dalam penelitian ini. perhitungan NPV menggunakan

Microsoft Excel yang datanya dapat dilihat dari Tabel 4.47. berikut.

Tabel 4.47.

Perhitungan Data NPV Ide Kreatif Kondisi Normal

\begin{tabular}{|l|cr|}
\hline \multicolumn{1}{|c|}{ Keterangan } & \multicolumn{2}{c|}{ Jumlah } \\
\hline Kas Keluar & $\mathrm{Rp}$ & $(113.971 .250)$ \\
\hline Kas Masuk Tahun 2014 & $\mathrm{Rp}$ & 75.212 .300 \\
\hline Kas Masuk Tahun 2015 & $\mathrm{Rp}$ & 272.211 .826 \\
\hline Kas Masuk Tahun 2016 & $\mathrm{Rp}$ & 766.672 .412 \\
\hline NPV & $\mathrm{Rp} 672.021 .152 .40$ \\
\hline
\end{tabular}

Sumber: Data Primer. diolah 
NPV yang diperoleh sebesar 672.021.152.40 yang berarti bahwa rencana pengembangan bisnis dapat dilakukan. Hal ini dibuktikan dengan nilai angka NPV lebih besar dari 0 (bertanda positif). sehingga dapat dikatakan layak.

3) Profitability Index (PI)

Dalam penelitian ini. perhitungan PI juga menggunakan Microsoft Excel yang datanya sebagai berikut.

Tabel 4.48.

Perhitungan Data PI Ide Kreatif Kondisi Normal

\begin{tabular}{|l|cr|}
\hline \multicolumn{1}{|c|}{ Keterangan } & \multicolumn{2}{c|}{ Jumlah } \\
\hline Kas Keluar & Rp & $(113.971 .250)$ \\
\hline Kas Masuk Tahun 2014 & Rp & 75.212 .300 \\
\hline Kas Masuk Tahun 2015 & Rp & 272.211 .826 \\
\hline Kas Masuk Tahun 2016 & Rp & 766.672 .412 \\
\hline \multicolumn{1}{|c|}{ PI } & & 6.896 \\
\hline
\end{tabular}

Sumber: Data Primer. diolah

Nilai PI yang diperoleh sebesar 6.896 yang menunjukkan bahwa penerimaan kas lebih besar 6.896 kali daripada pengeluaran. Dengan demikian. dapat disimpulkan bahwa rencana pengembangan bisnis Ide Kreatif dapat dilakukan karena nilai PI lebih besar daripada 1.

4) Internal Rate of Return

Perhitungan nilai IRR dalam penelitian ini juga dilakukan menggunakan Microsoft Excel pada Tabel 4.49. berikut.

Tabel 4.49.

Perhitungan Data IRR Ide Kreatif Skenario Normal

\begin{tabular}{|l|cr|}
\hline \multicolumn{1}{|c|}{ Keterangan } & \multicolumn{2}{|c|}{ Jumlah } \\
\hline Kas Keluar & $\mathrm{Rp}$ & $(113.971 .250)$ \\
\hline Kas Masuk Tahun 2014 & $\mathrm{Rp}$ & 75.212 .300 \\
\hline Kas Masuk Tahun 2015 & $\mathrm{Rp}$ & 272.211 .826 \\
\hline Kas Masuk Tahun 2016 & $\mathrm{Rp}$ & 766.672 .412 \\
\hline \multicolumn{2}{|c|}{ IRR } & \multicolumn{2}{c|}{$159 \%$} \\
\hline
\end{tabular}

Sumber: Data Primer. diolah 
Dari Tabel 4.49. di atas dapat dilihat bahwa IRR yang diperoleh mencapai $159 \%$. Tingkat bunga IRR lebih besar jika dibandingkan dengan suku bunga kredit retail dari BCA yaitu sebesar $10.60 \%$ per tahun. Dengan demikian dapat disimpulkan bahwa rencana pengembangan bisnis Ide Kreatif dapat dilakukan karena memberikan tingkat pengembalian lebih tinggi daripada suku bunga kredit.

c. Proyeksi Laporan Keuangan Kondisi Pesimis

Kondisi skenario pesimis menggunakan asumsi penjualan tidak sesuai dengan ekspektasi awal. sehingga mengalami penurunan sebesar 5\% berdasarkan wawancara yang dilakukan dengan CV. Karya Utama.

Perhitungan kondisi pesimis sebagai berikut.

Tabel 4.50.

Proyeksi Laporan Arus Kas Ide Kreatif Kondisi Pesimis

\begin{tabular}{|c|c|c|c|c|}
\hline Keterangan & Investasi (Rp) & $2014(\mathrm{Rp})$ & $2015(\mathrm{Rp})$ & $2016(\mathrm{Rp})$ \\
\hline \multicolumn{5}{|l|}{ Initial Cash Flow } \\
\hline Investasi Awal & 98.400 .000 & & & \\
\hline Net Working Capital & 15.571 .250 & & & \\
\hline Project Cost & 113.971 .250 & & & \\
\hline \multicolumn{5}{|l|}{ Operating Cash Flow } \\
\hline Penjualan & & 356.250 .000 & 667.968 .750 & 1.335 .937 .500 \\
\hline Harga Pokok Penjualan & & $(154.300 .000)$ & $(260.731 .250)$ & $(444.303 .750)$ \\
\hline Biaya Gaji & & $(120.000 .000)$ & $(132.000 .000)$ & $(145.200 .000)$ \\
\hline Biaya Listrik & & $(13.259 .753)$ & $(14.579 .938)$ & $(16.039 .089)$ \\
\hline Biaya Transportasi & & $(2.100 .000)$ & $(3.300 .000)$ & $(5.110 .000)$ \\
\hline Biaya Promosi & & $(10.000 .000)$ & $(15.000 .000)$ & $(20.000 .000)$ \\
\hline Biaya Penyusutan & & $(15.633 .333)$ & $(15.633 .333)$ & $(15.633 .333)$ \\
\hline Laba Sebelum Pajak (EBT) & & 40.956 .914 & 226.724 .229 & 689.651 .328 \\
\hline Pajak & & 5.119 .614 & 28.340 .529 & 86.206 .416 \\
\hline Laba Sesudah Pajak (EAT) & & 35.837 .300 & 198.383 .701 & 603.444 .912 \\
\hline Arus Kas Operasi & 113.971 .250 & 35.837 .300 & 198.383 .701 & 603.444 .912 \\
\hline Investasi pada NWC & & & & 15.571 .250 \\
\hline Terminal Cash Flow & & & & - \\
\hline Total Arus Kas & $(113.971 .250)$ & 35.837 .300 & 198.383 .701 & 619.016 .162 \\
\hline Kas Akhir & $(113.971 .250)$ & $(78.133 .950)$ & 120.249 .751 & 739.265 .912 \\
\hline
\end{tabular}

Sumber: Data Primer. Diolah 
Tabel 4.51.

Proyeksi Laporan Laba Rugi Ide Kreatif Kondisi Pesimis

\begin{tabular}{|c|c|c|c|}
\hline & $\begin{array}{l}2014 \\
(\mathrm{Rp})\end{array}$ & $\begin{array}{l}2015 \\
\text { (Rp) }\end{array}$ & $\begin{array}{c}2016 \\
\text { (Rp) }\end{array}$ \\
\hline \multicolumn{4}{|l|}{ PENDAPATAN } \\
\hline Penjualan & 356.250 .000 & 667.968 .750 & 1.335 .937 .500 \\
\hline Harga Pokok Penjualan & 154.300 .000 & 260.731 .250 & 444.303 .750 \\
\hline Laba Kotor & 201.950 .000 & 407.237 .500 & 891.633 .750 \\
\hline \multicolumn{4}{|l|}{ BEBAN USAHA } \\
\hline Beban Gaji & 120.000 .000 & 132.000 .000 & 145.200 .000 \\
\hline Beban Listrik & 13.259 .753 & 14.579 .938 & 16.039 .089 \\
\hline Beban Transportasi & 2.100 .000 & 3.300 .000 & 5.110 .000 \\
\hline Beban Promosi & 10.000 .000 & 15.000 .000 & 20.000 .000 \\
\hline Beban Penyusutan & 15.633 .333 & 15.633 .333 & 15.633 .333 \\
\hline Total Biaya Usaha & 160.993 .086 & 180.513 .271 & 201.982 .422 \\
\hline Laba/Rugi Sebelum Pajak & 40.956 .914 & 226.724 .229 & 689.651 .328 \\
\hline Pajak & 5.119 .614 & 28.340 .529 & 86.206 .416 \\
\hline Laba/Rugi Setelah Pajak & 35.837 .300 & 198.383 .701 & 603.444 .912 \\
\hline
\end{tabular}

Sumber: Data Primer. Diolah

Dari kedua proyeksi laporan keuangan di atas. maka selanjutnya akan

dihitung kriteria penilaian investasi secara finansial yang terdiri dari:

1) Payback Period (PP)

Tabel 4.52.

Perhitungan Payback Period Ide Kreatif Kondisi Normal

\begin{tabular}{|l|l|ll|}
\hline \multicolumn{1}{|c|}{ Keterangan } & \multicolumn{1}{c|}{ Jumlah } & \multicolumn{2}{c|}{ Akumulasi } \\
\hline Kas Keluar & $\mathrm{Rp} \mathrm{(113.971.250)}$ & $\mathrm{Rp}(113.971 .250)$ \\
\hline Kas Masuk Tahun 2014 & $\mathrm{Rp} \mathrm{35.837.300}$ & $\mathrm{Rp}$ & $(78.133 .950)$ \\
\hline Kas Masuk Tahun 2015 & $\mathrm{Rp} \mathrm{198.383.701}$ & $\mathrm{Rp}$ & 120.249 .751 \\
\hline Kas Masuk Tahun 2016 & $\mathrm{Rp} 619.016 .162$ & $\mathrm{Rp}$ & 739.265 .912 \\
\hline
\end{tabular}

Sumber: Data Primer. Diolah

Perhitungan Payback Period:

$1+(\operatorname{Rp} 78.133 .950 / \operatorname{Rp} 198.383 .701)=1$ tahun +0.39 tahun

0,39 tahun $\mathrm{x} 12$ bulan $=4,73$ bulan $=4$ bulan $+0,73$ bulan

0,73 bulan $\mathrm{x} 30$ hari $=22$ hari $\rightarrow 1$ tahun 4 bulan 22 hari 
Jadi. usaha pengembangan Ide Kreatif memerlukan waktu 1 tahun 4 bulan 22 hari untuk mengembalikan investasi awal modalnya. Waktu tersebut kurang dari 3 tahun. sehingga rencana pengembangan bisnis layak untuk dilakukan.

2) Net Present Value (NPV)

Dalam penelitian ini. perhitungan NPV menggunakan Microsoft Excel yang datanya dapat dilihat dari Tabel 4.53. berikut.

Tabel 4.53.

Perhitungan Data NPV Ide Kreatif Kondisi Normal

\begin{tabular}{|l|c|}
\hline \multicolumn{1}{|c|}{ Keterangan } & Jumlah \\
\hline Kas Keluar & $\operatorname{Rp~(113.971.250)~}$ \\
\hline Kas Masuk Tahun 2014 & $\operatorname{Rp~35.837.300~}$ \\
\hline Kas Masuk Tahun 2015 & $\operatorname{Rp~} 198.383 .701$ \\
\hline Kas Masuk Tahun 2016 & $\operatorname{Rp~} 619.016 .162$ \\
\hline NPV & $\operatorname{Rp~486.581.131,47~}$ \\
\hline
\end{tabular}

Sumber: Data Primer. diolah

NPV yang diperoleh sebesar 486.581.131,47 yang berarti bahwa rencana pengembangan bisnis dapat dilakukan. Hal ini dibuktikan dengan nilai angka NPV lebih besar dari 0 (bertanda positif). sehingga dapat dikatakan layak.

3) Profitability Index (PI)

Dalam penelitian ini. perhitungan PI juga menggunakan Microsoft Excel yang datanya sebagai berikut.

Tabel 4.54.

Perhitungan Data PI Ide Kreatif Kondisi Normal

\begin{tabular}{|l|c|}
\hline \multicolumn{1}{|c|}{ Keterangan } & Jumlah \\
\hline Kas Keluar & Rp (113.971.250) \\
\hline Kas Masuk Tahun 2014 & Rp 35.837.300 \\
\hline Kas Masuk Tahun 2015 & Rp 198.383.701 \\
\hline Kas Masuk Tahun 2016 & Rp 619.016.162 \\
\hline PI & 5,269 \\
\hline
\end{tabular}

Sumber: Data Primer. diolah 
Nilai PI yang diperoleh sebesar 5,269 yang menunjukkan bahwa penerimaan kas lebih besar 5,269 kali daripada pengeluaran. Dengan demikian. dapat disimpulkan bahwa rencana pengembangan bisnis Ide Kreatif dapat dilakukan karena nilai PI lebih besar daripada 1.

4) Internal Rate of Return

Perhitungan nilai IRR dalam penelitian ini juga dilakukan menggunakan Microsoft Excel yang datanya dapat dilihat pada Tabel 4.55. berikut.

Tabel 4.55.

Perhitungan Data IRR Ide Kreatif Skenario Normal

\begin{tabular}{|l|c|}
\hline \multicolumn{1}{|c|}{ Keterangan } & Jumlah \\
\hline Kas Keluar & $\operatorname{Rp~(113.971.250)~}$ \\
\hline Kas Masuk Tahun 2014 & $\operatorname{Rp~35.837.300~}$ \\
\hline Kas Masuk Tahun 2015 & $\operatorname{Rp~198.383.701}$ \\
\hline Kas Masuk Tahun 2016 & $\operatorname{Rp~} 619.016 .162$ \\
\hline \multicolumn{1}{|c|}{ IRR } & $121 \%$ \\
\hline
\end{tabular}

Sumber: Data Primer. diolah

Dari Tabel 4.49. di atas dapat dilihat bahwa IRR yang diperoleh mencapai $121 \%$. Tingkat bunga IRR lebih besar jika dibandingkan dengan suku bunga kredit retail dari BCA yaitu sebesar $10.60 \%$ per tahun. Dengan demikian dapat disimpulkan bahwa rencana pengembangan bisnis Ide Kreatif dapat dilakukan karena memberikan tingkat pengembalian lebih tinggi daripada suku bunga kredit.

\section{Kriteria Kelayakan}

Adapun kriteria kelayakan berdasarkan pembahasan aspek keuangan di atas. dapat dilihat pada Tabel 4.56. berikut. 
Tabel 4.56.

Kriteria Kelayakan Aspek Keuangan Ide Kreatif

\begin{tabular}{|l|c|c|c|c|c|}
\hline \multicolumn{1}{|c|}{ Indikator } & Syarat & $\begin{array}{c}\text { Kondisi } \\
\text { Normal }\end{array}$ & $\begin{array}{c}\text { Kondisi } \\
\text { Optimis }\end{array}$ & $\begin{array}{c}\text { Kondisi } \\
\text { Pesimis }\end{array}$ & Hasil \\
\hline $\begin{array}{l}\text { Payback } \\
\text { Period }\end{array}$ & PP <3 tahun & $\begin{array}{c}\text { 1 Tahun 3 Bulan } \\
7 \text { Hari }\end{array}$ & $\begin{array}{c}\text { 1 Tahun 1 Bulan } \\
\text { 21 Hari }\end{array}$ & $\begin{array}{c}\text { 1 Tahun 4 Bulan } \\
\text { 22 Hari }\end{array}$ & Layak \\
\hline $\begin{array}{l}\text { Net Present } \\
\text { Value }\end{array}$ & NPV>0 & $563.847 .806,86$ & $672.021 .152,40$ & $486.581 .131,47$ & Layak \\
\hline $\begin{array}{l}\text { Profitability } \\
\text { Index }\end{array}$ & PI $>1$ & 5,947 & 6,896 & 5,269 & Layak \\
\hline $\begin{array}{l}\text { Internal Rate } \\
\text { of Return }\end{array}$ & IRR $>10.60 \%$ & $137 \%$ & $159 \%$ & $121 \%$ & Layak \\
\hline
\end{tabular}

Sumber: Data Primer. Diolah

Dari Tabel 4.56. di atas. semua indikator mendapatkan hasil layak. Dengan demikian. rencana pengembangan bisnis Ide Kreatif dapat dilakukan. 


\section{DAFTAR PUSTAKA}

Febriyantoro, M. T. (2016). Pemikiran irasional para perokok. EKSIS, XI(2), 1907-7513.

Febriyantoro, M. T. (2018). The Role Of Entrepreneurial Campus In Establishing Of Students’ Entrepreneurial Mindset and Entrepreneurial Spirit. International Conference of Econimic Studies, 141-146.

Febriyantoro, M. T., \& Arisandi, D. (2018). Pemanfaatan Digital Marketing Bagi Usaha Mikro, Kecil Dan Menengah Pada Era Masyarakat Ekonomi Asean, $1(2), 61-76$. 